\title{
Advanced Multi-Product Coal Utilization By-Product Processing Plant
}

\author{
Final Report \\ Principal Authors: Thomas Robl and John Groppo
}

April 2007

U. S. Department of Energy Cooperative Agreement No. DE-FC26-05NT41781

Performance Period: November 8, 2004 - March 31, 2007

DOE Project Manager: Sai Gollakota

Center for Applied Energy Research

2540 Research Park Drive

University of Kentucky

Lexington, KY 40511 


\section{Disclaimer}

This report was prepared as an account of work sponsored by an agency of the United States Government. Neither the United States Government nor any agency thereof, nor any employees, makes any warranty, expressed or implied, or assumes any legal liability or responsibility for the accuracy, completeness, or usefulness of any information, apparatus, product, or process disclosed, or represents that its use would not infringe privately owned rights. Reference herein to any specific commercial product, process, or service by trade name, trademark, manufacturer, or otherwise does not necessarily constitute or imply its endorsement, recommendation, or favoring by the United States Government or any agency thereof. The views and opinions of the authors expressed herein do not necessarily state or reflect that of those of the United States Government or any agency thereof. 


\section{Acknowledgement}

This report was produced with the support of the U.S. DOE under Award No. DE-FC2605NT41781. This Cooperative Agreement was administered by the Office of Fossil Energy's National Energy Technology Laboratory under the Clean Coal Power Initiative during the period 08 November 2004 through 31 March 2007. CAER would like to acknowledge the participation of E.ON U.S. Kentucky Utilities' Ghent Generating Station where the pilot-scale field tests were conducted. Cemex U.S.A. participated in the market assessment studies. 


\section{Abstract}

The overall objective of this project is to design, construct, and operate an ash beneficiation facility that will generate several products from coal combustion ash stored in a utility ash pond. The site selected is LG\&E's Ghent Station located in Carroll County, Kentucky. The specific site under consideration is the lower ash pond at Ghent, a closed landfill encompassing over 100 acres.

Coring activities revealed that the pond contains over 7 million tons of ash, including over 1.5 million tons of coarse carbon and 1.8 million tons of fine $(<10 \mu \mathrm{m})$ glassy pozzolanic material. These potential products are primarily concentrated in the lower end of the pond adjacent to the outlet.

A representative bulk sample was excavated for conducting laboratory-scale process testing while a composite 150 ton sample was also excavated for demonstrationscale testing at the Ghent site. A mobile demonstration plant with a design feed rate of 2.5 tph was constructed and hauled to the Ghent site to evaluate unit processes (i.e. primary classification, froth flotation, spiral concentration, secondary classification, etc.) on a continuous basis to determine appropriate scale-up data.

Unit processes were configured into four different flowsheets and operated at a feed rate of 2.5 tph to verify continuous operating performance and generate bulk (1 to 2 tons) products for product testing. Cementitious products were evaluated for performance in mortar and concrete as well as cement manufacture process addition. All relevant data from the four flowsheets was compiled to compare product yields and quality while preliminary flowsheet designs were generated to determine throughputs, equipment size specifications and capital cost summaries.

A detailed market study was completed to evaluate the potential markets for cementitious products. Results of the study revealed that the Ghent local fly ash market is currently oversupplied by more than 500,000 tpy and distant markets (i.e. Florida) are oversupplied as well. While the total US demand for ultrafine pozzolan is currently equal to demand, there is no reason to expect a significant increase in demand.

Despite the technical merits identified in the pilot plant work with regard to beneficiating the entire pond ash stream, market developments in the Ohio River Valley area during 2006-2007 were not conducive to demonstrating the project at the scale proposed in the Cooperative Agreement. As a result, Cemex withdrew from the project in 2006 citing unfavorable local market conditions in the foreseeable future at the demonstration site.

During the Budget Period 1 extensions provided by the DOE, CAER has contacted several other companies, including cement producers and ash marketing concerns for private cost share. Based on the prevailing demand-supply situation, these companies had expressed interest only in limited product lines, rather than the entire ash beneficiation product stream. Although CAER had generated interest in the technology, a financial commitment to proceed to Budget Period 2 could not be obtained from private companies. Furthermore, the prospects of any decisions being reached within a reasonable time frame were dim. Thus, CAER concurred with the DOE to conclude the project at the end of Budget Period 1, March 31, 2007. The activities presented in this report were carried out during the Cooperative Agreement period 08 November 2004 through 31 March 2007. 


\section{Table of Contents}

$\begin{array}{lll}\text { Section } & \text { Page No. }\end{array}$

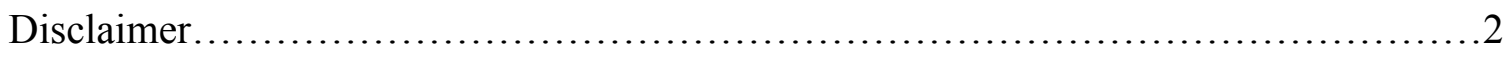

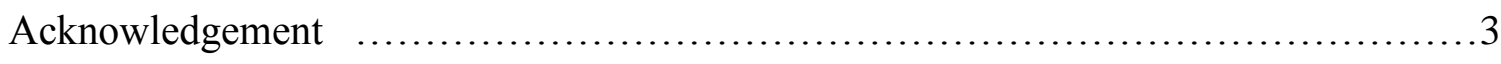

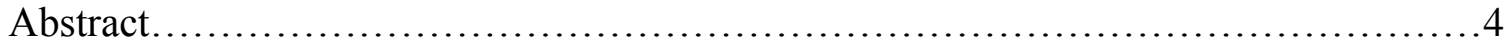

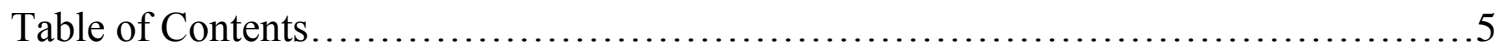

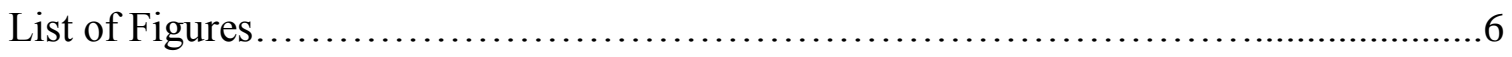

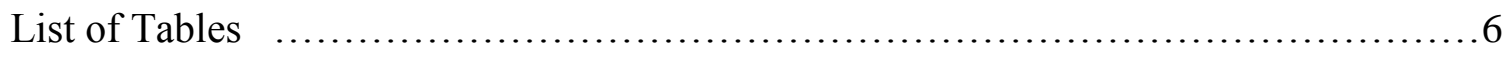

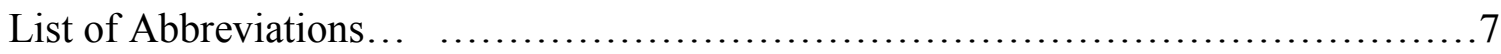

Technical Progress by Task $\ldots \ldots \ldots \ldots \ldots \ldots \ldots \ldots \ldots \ldots \ldots \ldots \ldots \ldots \ldots \ldots \ldots \ldots \ldots \ldots . . . \ldots$

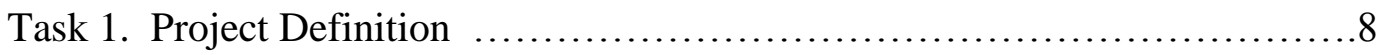

Subtask 1.1. Initial Sample Collection and Characterization.....................8

Subtask 1.2. Pond Assessment............................................. 8

Subtask 1.3. Bulk Sample Collection and Characterization...................... 8

Subtask 1.4. Unit Process Evaluation...................................... 9

Subtask 1.5. Product Evaluation............................................ 15

Subtask 1.6. Market Survey and Business Plan...............................17

Subtask 1.7. Plant Location and Infrastructure..............................27

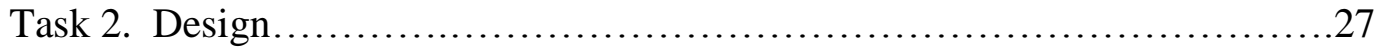

Subtask 2.1. Preliminary Plant Design...................................27

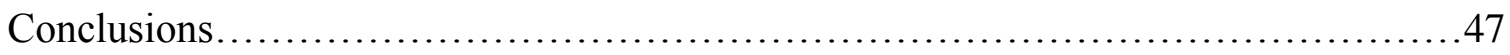




\section{List of Figures}

Page No.

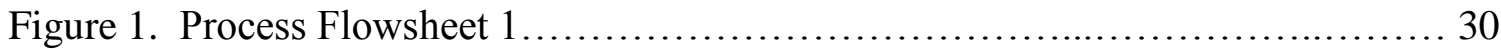

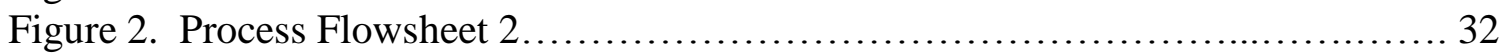

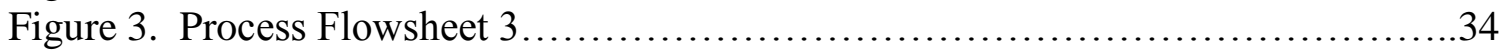

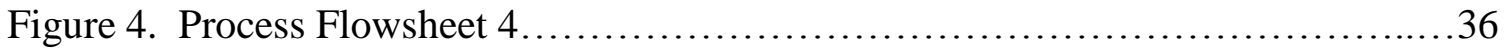

\section{List of Tables}

Page No.

Table 1. Competing Sources 100 Miles Radius from Ghent......................... 18

Table 2. Performance of Ultra Fine Pozzolans Compared to Cement Only. ............. 23

Table 3. Summary of Process Flowsheets Evaluated, 50 tph Basis..................... 26

Table 4. Determination of Equipment Installation Factors......................... 37

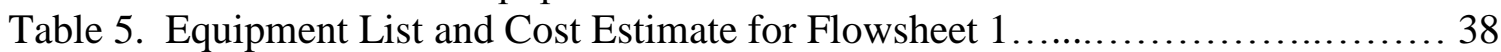

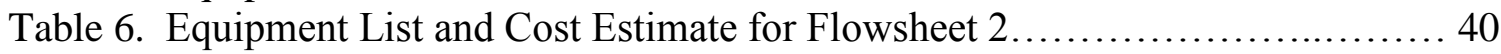

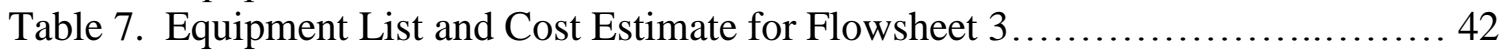

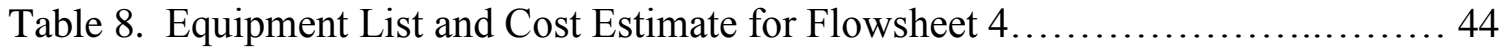

Table 9. Summary of Installed Plant Costs and Products Produced .................... 46. 


\section{List of Abbreviations}

$\begin{array}{ll}\text { AEA } & \text { Air Entraining Admixture } \\ \text { ASTM } & \text { American Society for Testing and Materials } \\ \text { Btu } & \text { British Thermal Units } \\ \text { CAER } & \text { Center for Applied Energy Research } \\ \text { EP } & \text { Econosizer Product } \\ \text { ESP } & \text { Electrostatic Precipitator } \\ \text { f.o.b. } & \text { Free On Board } \\ \text { FP } & \text { Flotation Product } \\ \text { FUFA } & \text { Ultra-Fine Ash (with flotation) } \\ \text { FWAA } & \text { Federal Highway Administration } \\ \text { GGBFS } & \text { Groung Granulated Blast Furnace Slag } \\ \text { gpm } & \text { Gallons per Minute } \\ \text { LG\&E } & \text { Louisville Gas and Electric Co. } \\ \text { LOI } & \text { Loss on Ignition } \\ \text { MK } & \text { Metakaolin } \\ \text { MW } & \text { Molecular Weight } \\ \text { NRMCA } & \text { National Ready Mix Concrete Association } \\ \text { NSF } & \text { Naphthalene Sulfonate Formaldehyde Condensate } \\ \text { PAM } & \text { Polyacrylamide } \\ \text { PEO } & \text { Polyethylene Oxide } \\ \text { ppm } & \text { Parts per Million } \\ \text { SAI } & \text { Strength Activity Index } \\ \text { SPP } & \text { Sulfonated Petroleum Product } \\ \text { tph } & \text { Tons per Hour } \\ \text { tpy } & \text { Tons per Year } \\ \text { TVA } & \text { Tennessee Valley Authority } \\ \text { USDoE } & \text { United States Department of Energy } \\ \text { UFA } & \text { Ultra Fine Ash (without flotation) } \\ \text { UFFA } & \text { Ultra Fine Fly Ash } \\ \text { USGS } & \text { United States Geological Survey } \\ & \end{array}$




\section{Technical Progress by Task}

\section{Task 1. Project Definition}

\section{Subtask 1.1. Initial Sample Collection and Characterization}

Status: Completed

Summary: The coal used by the Ghent power plant and the fly and bottom ashes produced were sampled during the pre-award phase of the project. The fly ash was collected from bins that were associated with the electrostatic precipitator collection fields. The Ghent plant uses two-field ESP and the bulk of the ash is collected in the first field. The samples were subjected to ultimate and proximate analysis utilizing standard ASTM techniques. The samples were ashed and subjected to X-ray fluorescence analysis for both major and trace elements using international ash and rock standards as calibration. Mercury was analyzed on a LECO Hg analyzer on a raw sample basis

The ash produced by the plant was found to be highly variable as the plant consumes high and low sulfur bituminous coal in Units 1 and 2, and a mixture of subbituminous and bituminous coal in Units 3 and 4. The ash produced reflected this consisting of an iron-rich $\left(\sim 24 \%, \mathrm{Fe}_{2} \mathrm{O}_{3}\right)$, aluminum rich $\left(\sim 29 \% \mathrm{Al}_{2} \mathrm{O}_{3}\right)$ and high calcium $(6 \%-7 \%, \mathrm{CaO})$ ash, respectively. The LOI of the ash typically was in the range of $5.5 \%$ to $6.5 \%$, but individual samples ranged from $1 \%$ to almost $9 \%$.

\section{Subtask 1.2. Pond Assessment}

Status: Completed

Summary: The lower pond at Ghent is a substantial body, covering more than 100 acres, with a volume that exceeds 200 million cubic feet. The sedimentation, stratigraphy and resource assessment of the in-place ash was investigated with vibracoring and three-dimensional, computer-modeling techniques. Thirteen cores to depths reaching nearly 40 feet were retrieved, logged in the field, and transported to the lab for a series of analyses for particle size, loss on ignition, petrography, x-ray diffraction, and x-ray fluorescence.

Collected data were processed using ArcViewGIS, Rockware, and Microsoft Excel to create three-dimensional, layered iso-grade maps, as well as stratigraphic columns and profiles, and reserve estimations. The ash in the pond was projected to exceed 7 million tons, and contain over 1.5 million tons of coarse carbon and 1.8 million tons of fine $(<10 \mu \mathrm{m})$ glassy pozzolanic material. The size, quality and consistency of the ponded material suggests that it is the better feedstock for the beneficiation plant than the ash that is currently produced.

\section{Subtask 1.3. Bulk Sample Collection and Characterization}

Status: Completed

Summary: Approximately 2 tons of pond ash was retrieved from the Ghent site and processed at CAER in Lexington, KY. The specific sampling location was determined from the data collected in Subtask 1.2 in order to obtain a bulk sample that would be representative of the ash that would be processed by the proposed plant.

The bulk sample was processed using continuous pilot-scale equipment to produce product streams that would be similar in characteristics and quality to what 
would be produced in commercial operation. This was necessary to evaluate the thickening and dewatering characteristics of the product slurries (Subtask 1.4).

\section{Subtask 1.4. Unit Process Evaluation}

Because of the significant amount of varied activities and effort involved in this subtask, a brief summary will be provided for each in order to clarify the results and status of specific activities.

\subsubsection{Unit Process Testing of Fly Ash}

The following Subtasks were completed using a mobile demonstration plant that was constructed and operated at the Ghent site. The demonstration plant was a self-contained facility with a feed rate of 2.5 tons/hr. In order to operate the demonstration plant with a consistent, representative feed, approximately 150 tons of ash was excavated with a back hoe from the same region of the pond used to complete Subtask 1.3. The entire 170 tons was pre-screened to remove at 3/8 inch to remove vegetation and minor amounts of bottom ash to prevent valve plugging during testing. Each of the unit processes was evaluated using a variety of operating conditions to determine appropriate scale-up data necessary to complete Task 2 .

\subsubsection{Hydraulic Classification}

\section{Status: Completed}

Summary: The classification testing was conducted using a continuous demonstration-scale primary classifier ( $4 \mathrm{ft}$ x $4 \mathrm{ft}$ discharge area) that was operated at a production rate of 1 to 6 tons/hr. The feed for all testing was prepared as a slurry by transferring the $-3 / 8$ " stockpiled ash into a 500 gallon primary mix tank with a conveyor that was fed by a Bobcat loader. The tank was filled with the appropriate amount of water and mixed by circulating with a centrifugal pump at a rate of $100 \mathrm{gpm}$. Once the desired pulp density was achieved, the contents of the primary mix tank were diverted to a second 500 gallon tank which served as the classification feed tank. As the slurry was transferred into the classification feed tank, it was passed across an oversize screen (6 mesh) to remove coarse ash and vegetation. The -6 mesh slurry was circulated by a centrifugal pump, again at a rate of $100 \mathrm{gpm}$, and agitated with a mechanical impeller.

To conduct classification testing, feed slurry was diverted into the primary classifier at the desired rate which was monitored with an ultrasonic flowmeter. The feed slurry enters the primary classifier through a constant-head feed box in order to minimize fluctuations. The feed slurry enters near the base of the primary classifier and impinges on an inclined plate to divert the particles upward. Fine particles remain in suspension and overflow the device while coarse particles settle and are removed from the base of the classifier by a variable speed pump. To ensure feed consistency, preliminary tests were conducted by re-circulating the classifier products (overflow and underflow) back to the classification feed tank, so as to operate in a closed slurry loop.

Tests were conducted by allowing the classifier to operate at the desired conditions for a minimum of 30 minutes, regularly checking the flow rate of each product stream (i.e., overflow, underflow and feed), and then obtaining representative samples of 
each product. Samples were returned to the laboratory where they were weighed, filtered and dried to determine percent solids and a detailed size distribution by a combination of screening and laser diffraction. During testing, an additional set of slurry samples were also taken in known volume containers to accurately determine the specific gravity of the slurry so that an accurate mass balance for each test could be calculated.

Although good classification results were achieved under a variety of operating conditions, coarse rejection efficiency decreased with increasing feed rate. It was determined that the maximum feed rate to the primary classifier for efficient classification should be 50 gpm of slurry at $15 \%$ solids with a throughput of 2.3 tons $/ \mathrm{hr}$. Primary classification was shown to be effective for rejecting coarse $(+100$ mesh) material from the pond ash while maintaining high recovery of -100 mesh and particularly $-5 \mu \mathrm{m}$ ash. The classifier used was capable of efficiently providing this separation under a variety of feed rates and pulp densities, but +100 mesh rejection decreased with increasing feed rate. Operating the classifier at a feed rate of 40 to 50 gpm provided the primary classification desired to meet the project objectives.

In summary, the best results obtained with primary classification were met at a feed rate of 40 to $60 \mathrm{gpm}$. Higher feed rate results in poor classification and poor rejection of coarse solids while lower feed rate diminishes both yield and recovery of ultrafines. In regards to feed solids, operating at high feed solids (i.e. 25\%) provided reduced rejection of +100 mesh solids when the feed rate was higher than 40 gpm.

\subsubsection{Batch Flotation}

\section{Status: Completed}

Summary: This Subtask was completed using laboratory flotation equipment to assess the flotation characteristics of the Ghent pond ash. The feedstock used was from the bulk sample obtained in Subtask 1.3. A composite, representative sub-sample was obtained and classified to simulate primary classification to reject +100 mesh material. The -100 mesh slurry was then evaluated using a release analysis, which is a series of batch flotation rougher, cleaner, and scavenger stages. The release analysis is commonly used in flotation evaluation to determine the limits of separation that can be achieved by froth flotation.

Release analysis showed that froth flotation could effectively be used to reduce the classified ash from $4.5 \%$ LOI to the target grade of $2.5 \%$ LOI with a yield as high as $90 \%$. The corresponding froth product could have a grade as high as $20 \%$ LOI.

Although the froth grade achieved was lower than desired for a high-grade fuel product, higher grade froth products could only be achieved by flotation with higher LOI tailings grade. The only means of changing the results predicted by the release analysis would be to change the liberation of un-burned carbon by grinding, an option not considered as economically viable for this project since the froth product is not a primary product. The role of froth flotation is simply to reduce the amount of unburned carbon in the flotation tailings to enable its use as a pozzolan.

Addition batch flotation on classified ash showed that the desired tailings grade of $2.5 \%$ LOI could be achieved with 1.5 to $2 \mathrm{lbs}$ of collector/ton and less than $0.8 \mathrm{lbs} /$ ton of frother. The collector used (SPP) was a mixture of $90 \%$ \#2 fuel oil and $10 \%$ petroleum sulfonate while the frother was Ciba F948, a water soluble mixed glycol product. 


\subsubsection{Pilot Plant Flotation}

Status: Completed

Summary: Froth flotation testing was conducted on the primary classification overflow slurry of the demonstration plant in order to assess the effectiveness of froth flotation at reducing the LOI of the overflow slurry. During flotation testing, the feed solids to primary classification were maintained at 12 to $15 \%$ solids and the underflow withdrawal rate was maintained at $6 \%$ of the feed rate in order to achieve effective rejection of coarse (+100 mesh) solids and effective recovery of $-5 \mu \mathrm{m}$ ash.

The primary classifier overflow flowed by gravity to a bank of 4 Denver mechanical flotation cells (2'x2'x2' each). Individual cell froth height was adjusted by means of gate valves and froth was removed by mechanical scrapers. Flotation reagents (collector and frother) were metered into the air intake of the first flotation cell.

The froth product was collected in a launder which drained to a holding area while the flotation tailings drained from the last cell into a similar drainage line. After the cells were operating at equilibrium for a period of time equivalent to 3 times the retention time, samples of the flotation feed, froth, and tailings were obtained for laboratory analyses of \% solids, LOI, and size distribution by sieving and laser diffraction. An additional set of samples were taken in fixed volume containers to determine the pulp specific gravity on site. This data, along with timed flow samples, were tabulated to ensure an accurate mass balance for each test.

In order to reduce the LOI of the primary classifier overflow to below $3 \% \mathrm{LOI}$, a minimum retention time of 6 minutes was required, using $1.2 \mathrm{lbs} /$ ton collector and 0.23 lbs/ton frother. Reagent costs to provide acceptable grade tailings were 0.50 to $1.00 \$ /$ ton of flotation feed and longer retention times did not provide any significant benefit in terms of performance.

Increasing collector dosage reduced tailings LOI, but also reduced tailings yield and correspondingly reduced froth grade. Increasing frother dosage effectively decreases tailings LOI, however at higher frother dosages $(>0.3 \mathrm{lbs} / \mathrm{ton})$ the quantity of froth that is generated is excessive and could potentially create handling challenges. Since higher frother dosages do not provide significantly better tailings grade, it is highly recommended that frother dosages be minimized from both a cost and handling perspective.

All of the demonstration plant flotation data was consistent with predictive results from the release analysis. The release analysis for the composite feed sample contained $3.8 \%$ LOI, which was reduced to $2.5 \%$ LOI with a yield of $90 \%$. The corresponding froth product (10\% yield) contained $18 \%$ LOI. The release analysis also shows that the tailings could be reduced to as low as $1.5 \%$ LOI with a yield of $62 \%$ and a correspondingly lower froth grade $(7 \%$ LOI). The close proximity of the flotation data to the release analysis indicates that most of the results obtained in the demonstration plant operation were quite close to the limits of separation that flotation could achieve. Further testing to assess the effect of variables such as feed solids, froth depth, etc., would not produce results that would be better than the release analysis shows. The only means of changing the release analysis is to change the liberation of the carbon in the feed or change the feed sample altogether.

In summary, froth flotation was evaluated to reduce the LOI of the primary classifier overflow to below 3\%. A minimum retention time of 6 minutes was required to 
provide LOI reduction to $2.5 \%$ LOI using $1.2 \mathrm{lbs} /$ ton collector and $0.23 \mathrm{lbs} /$ ton frother. Reagent costs to provide acceptable grade tailings were 0.50 to $1.00 \$ /$ ton of flotation feed. Demonstration plant flotation results were consistent with release analysis results, indicating that no further significant improvement in flotation performance could be expected with additional testing.

\subsubsection{Pozzolan Thickening/Filtration}

Status: Completed

Summary: Testing was conducted with a variety of filter media samples in order to assess the feasibility of using vacuum filtration with conventional media to recover the ultrafine ash (UFA) product. This testing was conducted in response to recommendations by technical representatives from several filter manufacturing companies. The filtration media samples evaluated were a variety of monofilament, multifilament and combination polypropylene fabrics.

The evaluation was conducted using commercial media samples mounted on a batch filtration apparatus with 4 mesh media support. A suspension of UFA was filtered through the media and rate was determined electronically. After filtration was completed, cake moisture was determined and solids recovery was also determined by filtering the solids in the filtrate with a Millipore filter $(0.5 \mu \mathrm{m})$.

A total of 5 media candidates were evaluated. One multifilament candidate, $853 \mathrm{~F}$ was eliminated since the entire sample passed through media and no solids recovery occurred. All of the media candidates tested provided essentially the same cake moisture after a cycle time of 2 minutes (i.e. 28.5 to $29 \%$ moisture). The fastest filtration results during cake formation were obtained with $901 \mathrm{~F}$ multifilament with M929 monofilament providing the slowest. In terms of solids capture, M929, 901F, and 950A recovered 97 to $99.5 \%$ of the feed solids in the cake while 950B provided $90.9 \%$ solids capture.

Based on the results obtained from batch filtration testing, it was determined that the most suitable filter media for this substrate in terms of filtration rate, solids capture, and cake moisture was 901F multifilament fabric.

Although the fabrics evaluated provided good results for filtering such fine particulates, it was apparent that the filtration rate was inadequate for an industrial process. Cake thickness was too small $(<2 \mathrm{~mm})$ to ensure cake removal. In order to continuously dewater a significant amount of UFA with a reasonably sized filter, it would be necessary to use flocculating agents.

A variety of flocculants (anionic, nonionic and cationic) and molecular weights (4 to 16 million) were screened using standard jar tests to determine the appropriate chemistry that would provide effective floc formation. After the initial screening, it was determined that two different chemistries would be appropriate; polyethylene oxide (PEO) and polyacrylamide (PAM). A molecular weight series of PEO products was obtained from Dow Chemical and a similar series of PAM products was obtained from Cytec, Inc. Settling tests were conducted and it was determined that the lower molecular weight products (i.e. 4 million MW) provided the most desirable floc structure. Higher molecular weight flocculants, while providing faster setting rates, provided large, fluffy flocs which would entrain moisture in the floc structure during filtration. In addition, the fast settling rate provided poor clarity. 
Settling tests were conducted in 1 liter glass cylinders. At a dosage of $1 \mathrm{ppm}$ PEO, the settling rate of the flocculated UFA was 4.5 inches/minute for the first 2 minutes and decreased to 3 inches/minute after 5 minutes. Essentially the same results were obtained with a dosage of $5 \mathrm{ppm}$. A more desirable initial settling rate of 6 inches/minute was obtained with a dosage of $2.5 \mathrm{ppm}$ PEO, while increasing the dosage to $10 \mathrm{ppm}$ was not advantageous at all. For effective thickener operation, an initial settling rate of 4 to 12 inches/minute is desirable. This settling rate provides adequate solids settling and compaction while maintaining overflow clarity.

The initial settling rate obtained with 5 ppm PAM was very high (22 inches/minute). While this may seem beneficial, it is in practice much too fast to maintain consistent thickener operation in terms of both solids compaction and overflow clarity. Based upon these results, it was determined that the most appropriate flocculant treatment for UFA would be 5 ppm PEO.

In order to assess the filtration characteristics of flocculated UFA, a series of batch filtration tests was conducted on a UFA slurry produced using laboratory pilotscale equipment under conditions that would be anticipated during commercial operation. The slurry (5\% solids w/w) was flocculated with 5 ppm PEO and the settled solids $(25 \%$ solids w/w) were recovered for filtering using F901 media. At a cake thickness of 4.3 $\mathrm{mm}$, cake formation occurred at 30 seconds and the resulting cake moisture after 2.5 minutes was $32.1 \%$ moisture. Increasing the cake thickness to $5.8 \mathrm{~mm}$ increased the cake formation time to 45 seconds and provided a cake with $31.0 \%$ moisture. Further increasing the cake thickness to $7.3 \mathrm{~mm}$ increased cake formation to 53 seconds and cake moisture was $31.8 \%$. For comparison, when no flocculant was used, cake formation occurred at 90 seconds (1 mm cake thickness) and the final cake moisture was $29.0 \%$.

A series of test were conducted during filed demonstration testing to evaluate continuous filter performance. These tests were conducted using an Eimco vacuum drum filter (12" wide x 18" diameter drum) with $901 \mathrm{~F}$ media.

Flocculated (5 ppm PEO) UFA (25\% solids w/w) was pumped into the vacuum filter tub. The slurry feed rate was adjusted to maintain a constant tub level and the filter was allowed to operate under fixed conditions for 15 minutes. Timed samples of the discharged filter cake and filtrate were simultaneously taken and analyzed. The procedure was repeated for different cycle times. Maximum throughput $(115 \mathrm{lb} / \mathrm{hr})$ and dry cake rate $(25 \mathrm{lb} / \mathrm{ft} 2 / \mathrm{hr})$ were achieved at a cycle time of 1.25 minutes. Under these conditions the cake moisture was $30.5 \%$ with $85 \%$ solids capture. Increasing cycle time not did not reduce cake moisture but did reduce the dry cake rate and throughput. The longer cake formation time during the longer cycle time did not provide additional cake deposition, suggesting that the cake resistance is quite high. At shorter cake formation time (i.e. shorter cycle time), dry cake rate and throughput also were diminished with a modest reduction in moisture. These results indicate that there is an optimum cake thickness and it is achieved at a cycle time of 1.25 minutes with this filter.

In summary, the proper flocculant to provide satisfactory thickening and clarity results on the UFA product is PEO at a dosage of $5 \mathrm{ppm}$ on a slurry basis. These conditions provide a settling rate of 6 inches/minute and settled solids concentrations of over $50 \%$ solids by weight. PEO has been used in numerous concrete applications as a viscosity reducer and will not present any adverse effects to cement chemistry, particularly when used at such a minimal dosage. Continuous vacuum filtration (1.25 
minute cycle time) with the proper filter medium provided a product with sufficient moisture reduction to enable direct use in concrete (30\% moisture).

\subsubsection{Froth Filtration Analysis}

Status: Completed

Summary: Filtration evaluation of the froth product has been completed using batch and continuous vacuum filtration approaches described in Subtask 1.4.1.4. For each of the evaluations, a representative composite froth product generated during demonstration testing was used. No addition media evaluations were conducted and the same media (multifilament 901F) was used.

Cake moisture with 2 minute cycle time was $39.4 \%$ moisture and the filtration rate was $24 \mathrm{lb} / \mathrm{hr} / \mathrm{ft}^{2}$. The low filtration rate is attributed to the dilute pulp density of the froth product ( $10 \%$ solids) while the high cake moisture is caused by the poor froth grade ( $21 \%$ LOI) and the porous nature of the unburned carbon. The addition of flocculant (5 ppm) did not improve cake moisture or throughput.

Although the cake moisture of the filtered froth product is high, most of the remaining water was within the pore structure of the carbon and the cake did not present unusual handling difficulties. Nevertheless, dewatering the froth product presents several technical challenges because the froth grade may be too low $(2700 \mathrm{Btu} / \mathrm{lb})$ to justify the expense of a more complex dewatering circuit, such as the installation of a thickener in order to reduce the volume of water that must be removed by filtration.

One other option would be to combine the coarse carbon from the spiral circuit with the froth product. The addition of $2.5 \mathrm{wt} \%$ coarse carbon did not reduce cake moisture, but more than doubled the filtration rate to $58.5 \mathrm{lb} / \mathrm{hr} / \mathrm{ft}^{2}$. Further increasing the amount of coarse carbon to $8.6 \%$ by weight further increased throughput to $97.8 \mathrm{lb} / \mathrm{hr} / \mathrm{ft}^{2}$ at the same moisture content.

One additional option worthy of consideration would be collecting the froth product in a lined drainage area until sufficient quantity was accumulated to warrant excavation and stockpiling onto a drainage pad. This would effectively eliminate the need for froth filtration while producing a product with similar moisture content and handling properties.

\subsubsection{Dryer Evaluation}

Status: Completed

Summary: Dryer evaluations were conducted in consultation with thermal dryer manufacturers familiar with the application and product end use. To produce a dry product, fuel requirement will be 1100 Btu to evaporate 1 pound of water. Considering the scale of the proposed operation and volatility of fuel prices, the use of thermal drying presents a serious economic impediment to the successful completion of this project. An even greater challenge is the air permits required to construct and operate a dryer at the proposed facility.

Since the intended use of the pozzolan and UFA is in concrete, and water must be added, evaluations were completed to prepare these products as stable slurries containing 65 to $70 \mathrm{wt} \%$ solids. With this scenario, the UFA product would be recovered from the vacuum filter as a cake containing $70 \%$ solids. The cake would be sheared in a highshear mixer to prepare a pumpable slurry. Several dispersants are being evaluated to 
promote slurry stability. At $60 \%$ solids, these slurries exhibit a viscosity of $2.3 \mathrm{~Pa}$-sec after 24 hours which remains essentially unchanged for 7 days. Although using this approach would incur the additional cost of transporting water, the cost of thermal drying would be eliminated. In addition, the necessity of dry particulate collection and storage silos would be replaced by pumps and slurry tanks.

\subsubsection{Unit Process Testing of Bottom Ash}

Status: Completed

Summary: The process stream enriched in bottom ash reports to the reject stream of the primary classifier. Examination of this product revealed a significant proportion of unburned coal, an ash contaminant that would likely preclude the use of bottom ash as an aggregate. Unburned coal is commonly rejected from coal pulverizers and frequently contains pyrite. Spiral concentration effectively rejects pyrite, but not binary particles of coal and pyrite, which exhibit a specific gravity similar to that of porous bottom ash. As such, complete elimination of pyrite from bottom ash at the Ghent site is not likely and any lightweight aggregate produced may present the potential to develop iron stains in the finished product. However, if bottom ash currently produced at Ghent can be isolated from mill rejects, the potential to produce a marketable lightweight aggregate certainly exists.

Spiral concentration testing of the primary classifier underflow produced a marketable fuel product containing $5800 \mathrm{Btu} / \mathrm{lb}$. This product reports to the outside race of the concentrating spirals along with most of the water and misplaced fines in the spiral circuit. Dewatering is accomplished with a vibrating dewatering screen that effectively removes water and misplaces fine ash.

An additional product stream may be generated from spiral concentration since spherical magnetic particles are readily concentrated on the inside spiral race. This product was not considered in this evaluation and the addition of a rotary magnet would be necessary to produce a heavy media grade magnetic product.

\section{Subtask 1.5. Product Evaluation}

\subsubsection{Pozzolan Testing}

Status: Completed

Summary: Product evaluations of the UFA and pozzolan products in masonry and concrete have been completed. These evaluations were conducted using bulk composite products produced from demonstration plant operation. A brief summary of each phase of product testing follows.

Product Evaluations in Mortar: As expected, flowsheets not incorporating secondary classification produced products that were coarser. As such, the levels of water reduction achieved by these coarser products were also lower. The primary classification product (EP) product achieved a Strength Activity Index (SAI) of $85 \%$ of control strength in 7 days, $100 \%$ in 28 days and $130 \%$ in 56 days. The froth flotation product (FP) product performed similarly after 7 and 28 days, but achieved only $103 \%$ of control in 56 days. The highest strengths were obtained with the finer products produced by secondary classification with (FUFA) and without (UFA) flotation. Several bulk products were 
produced under a variety of operating conditions, with the finest products producing the higher strengths. Both UFA and FUFA products provided SAI of 102 to $110 \%$ of control in 7 days and 126 to $140 \%$ of control in 56 days. The higher dosages of air entraining admixture (AEA) to achieve constant air for the finer products is attributed primarily to increased fineness.

Product Evaluations in Concrete: Concrete testing was conducted using a Kentucky Transportation Pavement Mix design and substituting Trimble ash or UFA at a substitution rate of $20 \%$. The Trimble ash achieved $87 \%$ of control strength after 7 days and increased to $102 \%$ after 56 days. Two series of tests were conducted with UFA and although there were some differences particularly for the early strengths, the UFA outperformed the Trimble ash with $87-90.5 \%$ of control after 7 days, 105 to $107 \%$ after 28 days and 109.5 to $112 \%$ after 56 days.

Another series of concrete cylinders were poured using a Kentucky Transportation Cabinet High Performance Mix Design (MA designation). The UFA cylinders showed an expected delay in strength development during the early stages of curing and outperformed the control after approximately 20 days.

At 5\% UFA substitution, SAI was $101 \%$ after 1 and 7 days and increased to $106 \%$ after 28 days. At $15 \%$ substitution, SAI decreased to $89.5 \%$ after 1 day and $98 \%$ after 7 days, but the longer term strength gains were apparent after 28 days as a SAI of $113 \%$ was attained. At $25 \%$ substitution, early strengths were diminished and again, a SAI of $119.5 \%$ was achieved after 28 days. At the highest substitution level tested (35\%), early strengths were the lowest and SAI increased to $105 \%$ after 28 days. These results illustrate that higher substitution levels certainly delay early strength development, but surpass control strength after 28 days while lower substitution levels provide both early and longer term strength.

One of the most significant benefits provided by using UFA in concrete mix designs is the improved resistance to chloride permeability. While it has been known for some time that using fly ash in concrete reduces permeability, using finer ash provides a significant improvement in this criterion. Chloride permeability testing was conducted using four different concrete mixes: control, 20\% Trimble ash, 20\% UFA, and 40\% UFA. Chloride permeability was improved when Trimble ash was used. Significant further reductions were demonstrated when UFA was used, achieving an ASTM Chloride Rating of Very Low.

The effect of Trimble ash and UFA on concrete flexural and tensile strength were also evaluated. Results showed that marginal improvements in flexural strength were realized with Trimble ash and were somewhat higher when UFA was used in the mix design. Tensile strength was essentially unchanged when UFA was used and decreased for the Trimble ash.

\subsubsection{Specialized Cement Additive Evaluations \\ Status: Completed}

Summary: While the traditional approach to using fly ash in concrete is to utilize the ash as a direct replacement for Portland cement in concrete, an alternative approach was considered, namely as a process addition in the production of cement clinker. This approach offers several potential advantages for the cement kiln. Most notably, 
production capacity can be increased with minor capital investment by essentially extending the clinker by incorporating low levels (2.5 to 5\%) of UFA into the clinker itself. This alternative would be lower in cost to the more traditional approach of using ground granulated blast furnace slag (GGBFS) at the same levels. Results show that early and ultimate strengths can be improved, particularly at the $2.5 \%$ substitution level, while offering the advantage of improved grinding efficiency since the UFA is fine enough to preclude the necessity of further size reduction. A further benefit would be increased clinker production without increased $\mathrm{CO}_{2}$ generation. The advantages to the project are that the need for a thermal dryer would be eliminated and initial marketing of the UFA during the early stages of the commercial phase would be simplified.

To evaluate this approach, a series of laboratory scale evaluations were conducted using UFA produced as a stable, pumpable slurry ( $70 \%$ solids w/w) and the following solids properties: $\mathrm{d}_{50} 3-5 \mu \mathrm{m}$, density $2.41 \mathrm{~g} / \mathrm{cm}^{3}, 3.0 \% \mathrm{LOI}$, and $1.5 \% \mathrm{C}$. For comparison, $6 \mu \mathrm{m}$ Grade 120 GGBFS was also used. Mortar cubes were produced with either UFA or GGBFS at $2.5 \%$ and $5 \%$ substitution levels. The results are shown in Figure 4 and indicate that GGBFS and UFA slightly improved the 1 day strength activity at $2.5 \%$ substitution; at $5 \%$, strength was $94-96 \%$ relative to control. UFA consistently exhibited higher 1 day strength activity relative to GGBFS at $2.5 \%$ and $5 \%$, while GGBFS and UFA showed similar 28 day strength activity at $5 \%$, which ranged between $104-107 \%$. At $2.5 \%, 28$ day strength activity was higher for GGBFS (113\%) than for UFA $(99 \%)$.

Based upon these results and the potentially significant benefits that are offered by using UFA as a process addition, it is recommended that an industrial trial be conducted using 2.5\% UFA in accordance with ASTM C465. It is also recommended that mortar and concrete testing of industrially ground cement be conducted by CAER and Cemex.

\section{Subtask 1.6. Market Survey and Business Plan}

\subsubsection{Market Assessment}

Status: Completed

Summary:

\section{GHENT LOCAL MARKET}

- The local pozzolan Fly Ash market (fly ash used as a partial replacement for Portland Cement) has 500,000 tpy more supply than the current demand and Unit 2 at Trimble County will add about 125,000 additional tons to that surplus supply in 2008. The local price is $\$ 10$ to $\$ 14$ per ton. The main competition for Ghent would be the LG\&E Trimble County Station.

\section{DISTANT MARKETS}

- The export or distant pozzolan market also has a supply that exceeds demand in most of the locations. There are no existing barge terminals for fly ash in the markets identified. Most of the distant supplies into these markets are provided to the marketer at about no cost.

\section{ULTRAFINE POZZOLAN MARKET}


- The total demand in the United States for ultra fine pozzolans is in the range of 100,000 tpy, and that is currently equal to the supply. The current price for ultra fine pozzolans including UFFA is in the range of $\$ 200$ to $\$ 300$ per ton. There is no reason to expect demand to depart from its historical relationship to Portland cement demand.

A more detailed evaluation of the market assessment follows.

\section{Local Market}

This study considers a local market an area that is financially attractive when shipping by truck. This includes the cost of shipping and the competitive supply and demand situation in the market area. Since the Ghent site is in the Ohio River Valley which contains numerous other sources, the local market for each source is relatively close to the source. Sources and markets within 100 miles of the Ghent Station have been considered in this market study. Competing fly ash sources within this radius are shown in Table 1.

\section{TABLE 1 COMPETING SOURCES 100 MILE RADIUS FROM GHENT}

\begin{tabular}{|c|c|c|c|c|c|}
\hline PLANT & CITY & STATE & TONS/YR & CLASS & PRICE $^{1}$ \\
\hline CLIFTY CREEK & MADISON & IN & 177,000 & $\mathrm{C}$ & $\$ 21.00$ \\
\hline MILL CREEK & LOUISVILLE & KY & 200,000 & $\mathrm{~F}$ & $\$ 14.00$ \\
\hline TRIMBLE COUNTY & BEDFORD & KY & 120,000 & $\mathrm{~F}$ & $\$ 14.00$ \\
\hline MIAMI FORT & NORTH BEND & $\mathrm{OH}$ & 70,000 & $\mathrm{~F}$ & $\$ 10.00$ \\
\hline ZIMMER & MOSCOW & $\mathrm{OH}$ & 335,000 & $\mathrm{~F}$ & $\$ 10.00$ \\
\hline LAFARGE TERMINAL & INDIANAPOLIS & IN & 0 & $\mathrm{C}$ & $\$ 28.20$ \\
\hline
\end{tabular}

TOTAL

902,000

${ }^{1}$ \$/ton fob source

Table 1 indicated the total supply of fly ash in the local market is about 900,000 tpy. The population in the local market area is about 7,500,000 and the per capita cement consumption is about 0.38 tons per capita per year based on USGS cement consumption data and US Census population data. This study assumes fly ash is used in $70 \%$ of all Portland cement applications with a $20 \%$ substitution ratio. The fly ash demand is therefore estimated to be about 400,000 tons/yr in the local market. Consequently there is a surplus of 500,000 tons/yr of fly ash in the local market.

Fly ash replaces cement in concrete on about a 1:1 basis in concrete, and the price of cement is about $\$ 100$ per ton. Therefore, if the demand for fly ash was equal to or higher than the supply, the price should be in that range. In states where demand exceeds supply the price of fly ash is in the range of \$70/ton. The low price of fly ash in the local 
market as shown in Table 1 indicates the fly ash supply far exceeds the demand in the local market.

Trimble County and Clifty Creek are within 50 miles of the Ghent station and Mill Creek Miami Fort and Zimmer are within 100 miles. All of these sources are competitive in at least one, and in some cases two, of the local major markets which include Cincinnati, Louisville, Lexington, Indianapolis, and Dayton.

LG\&E's Trimble County Station would be the primary competitive source with pozzolan fly ash from Ghent. The Trimble County Station typically sells about 20,000 tpy in the local market at about $\$ 14$ per ton. In the near term, this 20,000 tpy is the maximum local market demand and price for pozzolan fly ash from Ghent. Demand is expected to grow very slowly over the 10 year economic life for the proposed plant investment and prices are not expected to increase significantly. The reasons for this are:

- Miami Fort and Zimmer have a freight advantage to the Cincinnati, Northern Kentucky, and Dayton markets,

- Indianapolis is nearly $100 \%$ a Class C market due to existing fly ash supply and is over 100 road miles away from Ghent

- Much of Louisville is a Class C market and LG\&E's Mill Creek Station supplies the Class $\mathrm{F}$ for this market.

Construction of the Ghent pozzolan fly ash plant would add significantly to the local market supply and the forecast price is less than estimated operating costs. Finally, the fly ash production at Trimble County is scheduled to double by 2008 when Unit 2 comes on line further adding to the oversupply. Therefore, the demand and price for Pozzolan Fly Ash produced at Ghent would both be very low in the local market.

\section{Export Markets}

In the contract documents export markets were defined as "distant" markets that could be reached by river barge or rail. Examples of distant markets given were Florida and the major cities along the Ohio and Mississippi Rivers. All of these markets except Miami, Florida have local fly ash sources and some have terminals for receiving and distribution of fly ash from distant sources. All fly ash terminals in these markets are rail served; none are river barge served. Though river transport is less costly per mile this mode requires significantly higher investment in larger silos and sophisticated unloading machinery compared to rail terminals. If barge transportation were economically attractive it would be utilized for supplying the existing demand.

None of the fly ash supplied to the distant markets is beneficiated. All of this fly ash comes from oversupplied markets in Texas and the Ohio River Valley. In these markets utilities offer these fly ashes at very low price or with a freight subsidy to encourage beneficial use rather than landfilling. The cost of beneficiating the Ghent fly ash is a significant disadvantage in comparison to these competing sources. Many of the distant sources selling non beneficiated fly ash in the studied distant markets have additional volume available to meet the demand growth forecast over the economic life of this plant project.

Following is a detailed assessment of the Florida and Ohio and Mississippi River market areas. 


\section{Florida}

- Florida can be reached by rail. The major markets are Tallahassee, Jacksonville, Orlando, Tampa Bay, and Miami.

- Fly ash is currently being railed into Florida from the Ohio River Valley and Texas.

- Fly ash from LG\&E's Mill Creek station is currently being railed into Florida and that station has much more high quality fly ash available to meet demand growth.

Following is a review of the fly ash market in each of the Florida markets.

\section{Tallahassee}

- This market is currently supplied by a beneficiated fly ash from Jacksonville, some Georgia fly ash with high trucking costs, and a distant fly ash from another Ohio River Valley source.

$\underline{\text { Jacksonville }}$

- This market is primarily supplied by a beneficiated fly ash from Jacksonville.

Orlando

- This market is currently supplied by fly ash from the local municipal power station, and from a power plant in Crystal River. Ground granulated blast furnace slag (GGBFS) is also produced in this market and competes with fly ash.

\section{Tampa Bay}

- This market is currently supplied by power plants in Crystal River and Tampa. Tampa Electric Company has announced plans to beneficiate all Big Bend Station fly ash adding over 200,000 tpy supply to this market.

- The southern portion of this market area is currently supplied by a terminal in Punta Gorda which distributes fly ash from Texas.

\section{$\underline{\text { Miami }}$}

- This market currently uses imported GGBFS and Texas fly ash from the Punta Gorda terminal.

- A major ready mix company is supplied with fly ash directly from Texas.

\section{Ohio and Mississippi River Valleys}

- Cincinnati and Louisville are part of the local market for Ghent product.

- The major markets on the Ohio and Mississippi River systems are Pittsburgh, Huntington-Ashland, Evansville, St Louis, Chicago, Quad Cities, Minneapolis, Memphis, Baton Rouge, and New Orleans.

- There are numerous coal-fired power stations along the Ohio, Illinois, and upper Mississippi Rivers creating an over supply of fly ash in most of these markets.

In summary, the demand in nearly all of these markets is being met with local fly ash sources or with distant sources that have fly ash prices near $\$ 0$ per ton fob the source. 
Therefore, the export markets have insufficient demand and value compared with the higher cost to produce pozzolan fly ash at Ghent.

A detailed review of each market follows.

\section{Pittsburgh}

- This Class F market is currently supplied by power plants within the local market by sources in western Pennsylvania and eastern Ohio.

\section{Huntington-Ashland}

- This Class F market is currently supplied by power plants within the local market by sources in western West Virginia and eastern Ohio.

\section{Evansville}

- This Class F market is currently supplied by power plants within the local market by sources at Petersburg, Indiana and Owensboro, Kentucky.

\section{$\underline{\text { St Louis }}$}

- This Class C market is currently supplied by power plants within the local market including Labadie and Festus, Missouri and two plants in western Illinois.

\section{Chicago}

- This Class $\mathrm{C}$ market is currently supplied by numerous power plants along the Illinois River in the local market plus additional power plants and a rail terminal in southern Wisconsin.

- For a few years a river barge terminal in Calumet City supplied Class C fly ash to southern Chicago, but this operation has stopped. It is unlikely that this terminal would be economically attractive.

\section{Quad Cities}

- This Class C market is currently supplied by power plants along the Mississippi within the local market.

\section{$\underline{\text { Minneapolis }}$}

- This Class C market is currently supplied by power plants within the local market.

Memphis

- This Class C market is currently supplied by a power plant within the local market, plus others in Missouri and Illinois.

- The TVA Cumberland station, a very large, high quality, Class F source, is within 150 miles

\section{Baton Rouge and New Orleans}

- This Class F market is currently supplied with beneficiated fly ash from a power plant in Hattiesburg, Mississippi. Future demand growth is projected to be accommodated by existing sources with excess supply capacity. 


\section{ULTRA FINE FLY ASH (UFFA)}

\section{Product Description}

UFFA is principally used as an admixture in concrete as a partial substitute for Portland cement to achieve very high strengths and excellent durability of the concrete. Due to high price, UFFA is specified for applications requiring high-strength $(>7,000$ psi), sulfate or corrosion resistance, and resistance to alkali silica reactivity. These high durability applications include high-rise buildings, highway bridges, and marine structures. A Federal Highway Administration (FWHA) study (Appendix 1) comparing 8 and $12 \%$ substitution of UFFA with baseline straight Portland cement concrete shows UFFA decreases chloride permeability and diffusion coefficient, and increases direct current resistivity of concrete.

UFFA is produced at one power station in Texas, and is marketed as Boral Micro 3. It is considered a niche product with low usage rates and high price relative to conventional fly ashes and Portland cement (2 - 4 times). UFFA has no ASTM specifications at this time, but Texas DOT has established the following specification:

1. Must conform to the TX DOT specifications for Class F fly ash.

2. Strength Activity Index (SAI) must be $85 \%$ of control at 7 days and $95 \%$ of control at 28 days.

3. $90 \%$ of the particles must be less than 8.5 microns, and $50 \%$ of the particles must be less than 3.25 microns.

4. Less than $6 \%$ may be retained on a 45 micron sieve when wet sieved.

5. Maximum moisture is $1 \%$.

6. Maximum Loss on Ignition (LOI) is $2.0 \%$.

\section{Market}

Because UFFA is a niche product with low demand and high price the market is national with a focus on the largest cities with tall concrete buildings, and coastal areas. Since little is known about the production and sales from the one known source for UFFA the demand and pricing of competitive ultra fine pozzolan products was used to define the market for UFFA. 


\section{Competitive Products}

The competitive products for UFFA from the Ghent station are Boral Micron 3, silica fume, and metakaolin. Table 2 compares the performance of Portland Cement concrete containing none of these admixtures with concrete containing various ultra fine pozzolans.

TABLE 2

\section{PERFORMANCE OF ULTRA FINE POZZOLANS COMPARED TO CEMENT ONLY}

\begin{tabular}{|l|c|c|c|}
\hline \multicolumn{1}{|c|}{ Property } & UFFA & Silica Fume & Metakaolin \\
\hline Water Requirement & Better & Worse & Neutral \\
\hline Air Content & Worse & Neutral & Neutral \\
\hline Workability & Better & Worse & Better \\
\hline Segregation and Bleeding & Better & Better & Better \\
\hline Heat of Hydration & Lower & Neutral & Neutral \\
\hline Setting Time & Slower & Neutral & Neutral \\
\hline Finishability & Better & Worse & Better \\
\hline Pumping & Better & Worse & Better \\
\hline Low Temp Curing & Worse & Neutral & Neutral \\
\hline High Temp Curing & Better & Worse & Better \\
\hline Early Strength & Worse & Better & Better \\
\hline Late Strength & Better & Better & Better \\
\hline Permeability and Absorption & Better & Better & Better \\
\hline ASR & Better & Better & Better \\
\hline Sulfate Attack & Better & Better & Better \\
\hline Corrosion of embedded steel & Better & Better & Better \\
\hline Carbonation & Worse & Worse & Worse \\
\hline Deicer Scaling & Worse & Worse & Worse \\
\hline Chemical Resistance & Better & Better & Better \\
\hline Plastic Cracking & Neutral & Worse & Neutral \\
\hline Drying Shrinkage and Creep & Neutral & Neutral & Neutral \\
\hline Expansion (Soundness) & Neutral & Neutral & Neutral \\
\hline Freeze-thaw resistance & Neutral & Neutral & Neutral \\
\hline Concrete Color & Darker & Dark & White \\
\hline
\end{tabular}

\section{Boral Micron 3}

Boral Mineral Technologies, a fly ash marketing company, separates this UFFA from Class F fly ash. Because it is fly ash, Boral 3 is generally an amorphous (glassy) alumina silica and silicate. Iron and calcium are the other major ( $>3 \%$ each) constituents. The particle shape is spherical with a mean diameter of 3 microns. Typical Class F fly ash has a mean diameter of 20-30 microns. Boral Micron 3 is gray colored due to the carbon and iron content. The product is packaged in 25 pound bags, one-ton super-sacs, and is also sold in bulk. 
There is no public data on the demand for this product, but CEMEX is a large supplier of ready mix concrete in Texas and has only used less than 1,000 tons of Boral Micron 3 in the first 3 quarters of 2006.

The price for this product FOB the Rockdale, TX Plant is,

- Bag/sack - \$340.00/ton

- Bulk - \$320.00/ton.

\section{$\underline{\text { Silica Fume }}$}

Silica fume (SF) is a byproduct from the production of ferrosilicon metals. It is amorphous (glassy) silica. Minor constituents ( $<10 \%$ total) are iron, calcium, magnesium, potassium, sodium, alumina, and carbon. Like fly ash, silica fume particles are spherical but with a mean diameter less than 0.2 microns. Silica fume has no ASTM specifications at this time.

Silica fume is typically used in concrete to reduce permeability, reduce ASR, and increase sulfate resistance. Concrete mixes with over $5 \%$ silica fume exhibit increased water demand and poorer workability compared to concrete with UFFA.

There are five domestic SF producers listed in the Silica Fume Association. The source locations are:

- Elkem Materials, Inc - Alloy, WV

- Norchem, Inc. - Beverly, OH and Selma, AL

- AIMCOR - Bridgeport, AL

- Simcala, Inc. - Mt. Meigs, AL

- SKW Metals and Alloys, Inc. - Calvert City, KY

The product is typically sold packaged in 25 pound bags and in bulk. There is no public data on the demand for this product so information was obtained from individuals who are familiar with the market.

- Elkem production is estimated at 30,000 tons per year

- Total US production is estimated at 100,000 tons per year

- Global consumption is estimated at 1,000,000 tons per year.

- Not all silica fume is used as an admixture in concrete.

- The largest ready mix concrete supplier in the United States consumes approximately 40 tons of silica fume per month totaling about 480 tons per year.

Based upon this information the estimated national demand for silica fume used as an admixture for concrete is approximately 50,000 to 100,000 tpy. One of the larger suppliers, (Elkem) lists the following, FOB their warehouse as of August 8, 2006:

- Bulk \$ 0.1025 / lb (\$205.00 / Ton)

- $25 \mathrm{lb}$ bag through $2000 \mathrm{lb}$ bags (Densified) $\$ 0.1425 / \mathrm{lb}$ ( $\$ 285.00 /$ ton)

- $50 \mathrm{lb}$ through $1650 \mathrm{lb}$ bags (Undensified) $\$ 0.1425 / \mathrm{lb}$ (285.00 / Ton) 
These prices are exactly the same as quoted in 2004 which implies ample supply and no increase in the perceived value of silica fume in the marketplace.

\section{$\underline{\text { Metakaolin }}$}

Metakaolin (MK) is a reactive alumino silicate pozzolan formed by calcining purified kaolinite at a specified temperature range. MK 3 is generally an amorphous (glassy) alumina silicate. Because the production of this product is controlled to make the products it contains limited amounts of crystalline material that is not reactive in concrete. The kaolinite ore is processed to remove impurities so only minor constituents remain including iron, calcium, and titanium. Because the material is milled like cement the particle shape of this product is angular. The literature for MetaMax indicates that this MK has a typical mean diameter of 1.2 microns, compared to 0.3 microns for silica fume, 3 microns for UFFA, and 20 to 30 microns for typical Class F fly ash. MetaMax and other MK are very white in color.

MK must meet ASTM C618 standards as a natural pozzolan. Appendix 5 lists an NRMCA Comparison of MK (PowerPozz) and silica fume which indicates similar performance for compressive strengths. The product is typically sold packaged in 55pound bags and 1-ton pound super-sacs, and is also sold in bulk. Larger producers of MK are BASF-Engelhard (MetaMax products), Burgess and others located in central Georgia between Macon and Augusta.

ISG purchased a company in South Carolina in 1999 and began producing MK. It was given the name CEMax, met the requirements of ASTM C-618 Type N, and reportedly replaced microsilica as a high-performance pozzolan. ISG shut down the operation after a few years.

There is no public data on the demand for this product, but the closure of the ISG facility indicates a relatively low demand. The price of their MK was $\$ 6.25-\$ 8.75$ per 50 lb bag ( $\$ 250-\$ 350 /$ ton).

\subsubsection{Capital Cost Estimations \\ Status: Completed}

Summary: A total of four flowsheet configurations were considered during this evaluation and tested at the pilot scale (2-5 tph feed rate). During testing, each unit process was rigorously evaluated by varying operating conditions and sampling to determine appropriate ranges of operation and performance. Data was compiled and used to determine equipment size specifications for a commercial demonstration plant. In order to compare the flowsheet configurations, a design basis of 50 tph solids feed rate was selected as the design basis. It was also assumed that the feed would be supplied to the process plant by a dredge, providing 1000 gpm slurry at $18 \%$ solids, operating specifications well within the operating range recommended by dredge vendors. A detailed description of each flowsheet configuration has been prepared as well as justification for specific equipment that will be required.

A description of the various unit processes with a summary of relevant sizing criteria has also been prepared. In some cases, equipment specifications and recommendations were provided by vendors, while in other cases the recommended equipment is generic to mineral processing applications and sizing was determined by flow rate calculations from the process flowsheets. In still other cases, equipment sizing 
was determined from results of pilot-scale testing conducted at the Ghent site. Since no technical determination has been made pertaining to the inclusion or elimination of a thermal dryer, capital cost estimation battery limits end with the production of damp products.

A summary of the process flowsheets evaluated is presented in Table 3. A more detailed description of each flowsheet has also been prepared. A total of four process configurations were considered and are compared using a $50 \mathrm{ton} / \mathrm{hr}$ feed solids basis. Flowsheet 1 was the simplest, incorporating only primary classification and spiral concentration and produced pozzolan and coarse carbon products. In Flowsheet 2, froth flotation was added and produced an additional fine carbon product. Flowsheet 3 included primary classification, spiral concentration and secondary classification and the resulting products were ultrafine ash (UFA) and coarse carbon. The most complex circuit evaluated was Flowsheet 4 which used primary and secondary classification and spiral concentration as well as froth flotation. With this configuration, three products were generated: UFA, coarse carbon, and fine carbon. An additional pozzolan product could potentially be recovered with this flowsheet, but was not considered in this evaluation.

\begin{tabular}{|c|c|c|c|c|c|}
\hline & & Flowsheet 1 & Flowsheet 2 & Flowsheet 3 & Flowsheet 4 \\
\hline \multirow{4}{*}{$\begin{array}{l}\text { Unit } \\
\text { Processes }\end{array}$} & Primary Classification & $\mathrm{X}$ & $\mathrm{X}$ & $\mathrm{X}$ & $\mathrm{X}$ \\
\hline & Spiral Concentration & $\mathrm{X}$ & $\mathrm{X}$ & $\mathrm{X}$ & $\mathrm{X}$ \\
\hline & Froth Flotation & & $\mathrm{X}$ & & $\mathrm{X}$ \\
\hline & Secondary Classification & & & $\bar{X}$ & $\bar{X}$ \\
\hline \multicolumn{2}{|c|}{ Installed Capital Cost } & $\$ 3.24 \mathrm{M}$ & $\$ 4.00 \mathrm{M}$ & $\$ 3.44 \mathrm{M}$ & $\$ 4.21 \mathrm{M}$ \\
\hline \multirow{2}{*}{ Additive Cost } & \$/plant feed ton & 0.029 & 0.622 & $1.00-1.35$ & $1.52-1.75$ \\
\hline & $\$ /$ product ton (pozzolan or UFA) & 0.033 & 0.828 & $3.88-4.48$ & $4.48-5.52$ \\
\hline \multirow{3}{*}{ Pozzolan } & tons $/ \mathrm{hr}$ & 46.5 & 43.7 & - & - \\
\hline & $\%$ LOI & 3.5 & 2.3 & - & - \\
\hline & $\%$ Moisture & 20 & 20 & - & - \\
\hline \multirow{3}{*}{ UFA } & tons $/ \mathrm{hr}$ & - & - & 14 & 13.1 \\
\hline & $\%$ LOI & - & - & 2.5 & 2.5 \\
\hline & $\%$ Moisture & - & - & 30 & 30 \\
\hline \multirow{2}{*}{ Coarse Carbon } & tons $/ \mathrm{hr}$ & 0.4 & 0.4 & 0.4 & 0.4 \\
\hline & Btu/lb (dmf) & 5400 & 5400 & 5400 & 5400 \\
\hline \multirow{2}{*}{ Fine Carbon } & tons/hr & - & 2.8 & - & 2.8 \\
\hline & Btu/lb (dmf) & - & 2700 & - & 2700 \\
\hline
\end{tabular}

Capital costs were determined by using verbal equipment quotes from various equipment vendors after sizing the major pieces of equipment to the required flow rates and performance specifications. Several chemical additives were used in the evaluations. Specifically, when froth flotation was employed, both frother and collector added. When secondary classification was used to produce UFA, a dispersant was necessary. For each flowsheet, flocculant was used to provide an adequate settling rate to minimize thickener size and maintain water clarity. During flowsheet testing, additive addition rates were monitored and recorded along with process flow rates to accurately determine the various 
dosages of each additive that were used. Data was compiled and is presented in two formats: \$/plant feed ton and \$/product ton. When reporting \$/plant feed ton, the costs simply represent the total additive consumption per ton of dry feed solids reporting to the primary classifier. Calculating the cost per ton of product was more complicated since there were in some cases multiple products generated. As such, the cost per product ton was determined based on the production of the principle product, i.e. UFA or pozzolan. Not surprisingly, as the processing complexity increased, additive costs increased as well. Comparing Flowsheet 1 (the simplest) and Flowsheet 4 (the most complex), additive costs increased from $\$ 0.029$ to $\$ 1.75 /$ ton of plant feed and $\$ 0.033$ to $\$ 5.52 /$ ton of UFA. The higher additive cost for Flowsheet 4 was due to the lower product yield with the more complex flowsheet. Not surprisingly, the lower product yield also produced products with potentially higher value.

\subsubsection{Business Plan}

Status: The activities in the business plan development were limited because of lack of private company participation and unfavorable local market conditions, which are described in the Market Assessment section.

\section{Subtask 1.7. Plant Location and Infrastructure}

\subsubsection{Selection of Specific Site}

Status: The Ghent station was evaluated for locating the demonstration plant. However, the local market conditions were not favorable for the sale of ash byproducts at competitive prices.

\subsubsection{Off-Site Cost Evaluation}

Status: Because of a lack of private financial support for the Ghent site demonstration, no further work was carried out on any ancillary services.

\section{Task 2. Design}

\section{Subtask 2.1. Preliminary Plant Design}

Status: A conceptual design was performed to obtain preliminary costs estimates and to facilitate market assessment.

Summary: In order to assess the technical and economic viability of constructing a commercial-scale processing facility, it was necessary to complete a preliminary plant design to determine the size of facility that would be envisioned as well as the quantity and quality of products that would be produced.

\subsubsection{Flow Diagrams}

Status: Completed

Summary: Although no specific decisions have been made pertaining to the flowsheet that will be utilized, four flowsheets were considered, and thus, four separate flow diagrams have been prepared summarizing the water and solids balances that will be encountered for the various flow streams. This information was compiled using

demonstration plant (2-5 tph feed rate) testing data. During testing, each unit process was 
rigorously evaluated by varying operating conditions and sampling to determine appropriate ranges of operation and performance. Data was compiled and used to determine equipment size specifications for a commercial demonstration plant. In order to compare the flowsheet configurations, a design basis of 50 tph solids feed rate was selected as the design basis. It was also assumed that the feed would be supplied to the process plant by a dredge, providing 1000 gpm slurry at $18 \%$ solids, operating specification well within the operating range recommended by dredge vendors. A detailed description of each flowsheet configuration follows.

Flowsheet 1: Flowsheet 1 (Figure 1) is the simplest configuration, consisting of essentially two unit processes; primary classification and spiral concentration that produce two distinct products; pozzolan and coarse carbon.

The dredge output is discharged into a sump or mix tank after assign through a trash screen ( $3 / 8$ inch) to remove primarily vegetation (i.e. weeds, sticks, etc.) and trivial amounts of misplaced coarse bottom ash or coal that may be present. The trash screen is primarily a cautionary device to prevent valve and pipe plugging.

The slurry is then pumped into a primary classifier for the specific objective of separating +100 mesh $(+150 \mu \mathrm{m})$ coarse ash and carbon from the finer ash. The primary classifier recommended is the Lewis Econosizer, which when fed at a constant feed rate provides particle separation based on particle setting velocity. This is an important operating consideration given the broad size distribution of ash that may be fed into the plant and fluctuations in the dredge output that can be anticipated. The primary classifier will consistently provide a 100 mesh separation provided the feed velocity is consistent. Thus the feed will be introduced into the classifier via a head box equipped with an overflow to maintain a constant head. The feed enters the base of the device and particle trajectory is diverted upward by a diverter plate. Particles too coarse to remain in suspension $(+150 \mu \mathrm{m})$ are withdrawn from the bottom of the device through an opening behind the diverter plate while finer particles $(-150 \mu \mathrm{m})$ overflow the device. Middling ports are provided to withdraw intermediate-size material from the device if necessary.

The primary classifier underflow (3.5 tph, 30\% solids) consists of coarse ash, coarse carbon, dense ash or 'magnetite' and misplaced fines. Ideally, this stream would be suitable for recovering lightweight aggregate, however, it was found during testing that there is an appreciable amount of coal in the ash pond. Unfortunately, the coal present was derived primarily from grinding mill rejects and includes locked grains of pyrite, the precursor to aggregate staining in concrete blocks. For this reason, the production of lightweight aggregate from the lower ash pond at Ghent is unlikely. There is, however, coarse unburned carbon present that is readily recoverable with concentrating spirals.

The spirals operate more efficiently at lower pulp density, so the primary classifier underflow is diluted to $12 \%$ solids. Most of the water, fine ash and carbon report to the outside spiral race which flows onto a dewatering screen (100 mesh) to recover the coarse carbon. The amount of coarse carbon present can vary significantly and will not affect spiral performance. The amount produced $(0.4 \mathrm{tph})$ was derived from pilot scale testing and will likely be higher (up to 2 tph) depending on the area being mined. The inside spiral race will concentrate spherical magnetic particles, potentially suitable for use as heavy media grade magnetite. Recovery of this product was not 
considered in the economic evaluation. Both the spiral rejects ( 0.6 tph and carbon dewatering screen effluent (9\% solids) are returned to the ash pond.

The primary classifier overflow (46.5 tph) consists essentially of -100 mesh ash, potentially marketable as pozzolan. In Flowsheet 1 , this dilute slurry is thickened and filtered to $70 \%$ solids. The thickener recommended is a conventional static thickener with a cantilever rake mechanism. Addition of suitable flocculant (2-5 ppm medium MW polyethylene oxide) provides adequate solids settling rate (6-12 inches/minute) with excellent clarity. Thickener overflow is returned to the pond, with the exception of 70 gpm that is used to dilute the spiral feed.

The design basis for the thickener underflow is $50 \%$ solids, a conservative value based on data obtained from manufacturers. Similarly, ash filter performance is also conservative at $30 \%$ moisture. Manufacturer testing confirmed that $20 \%$ cake moisture is readily achievable with a rotary vacuum drum filter.

With this configuration, 46.5 tph pozzolan is produced along with 0.4 tph coarse carbon. The amount of material returned to the pond is 3.1 tph at $1.6 \%$ solids. 


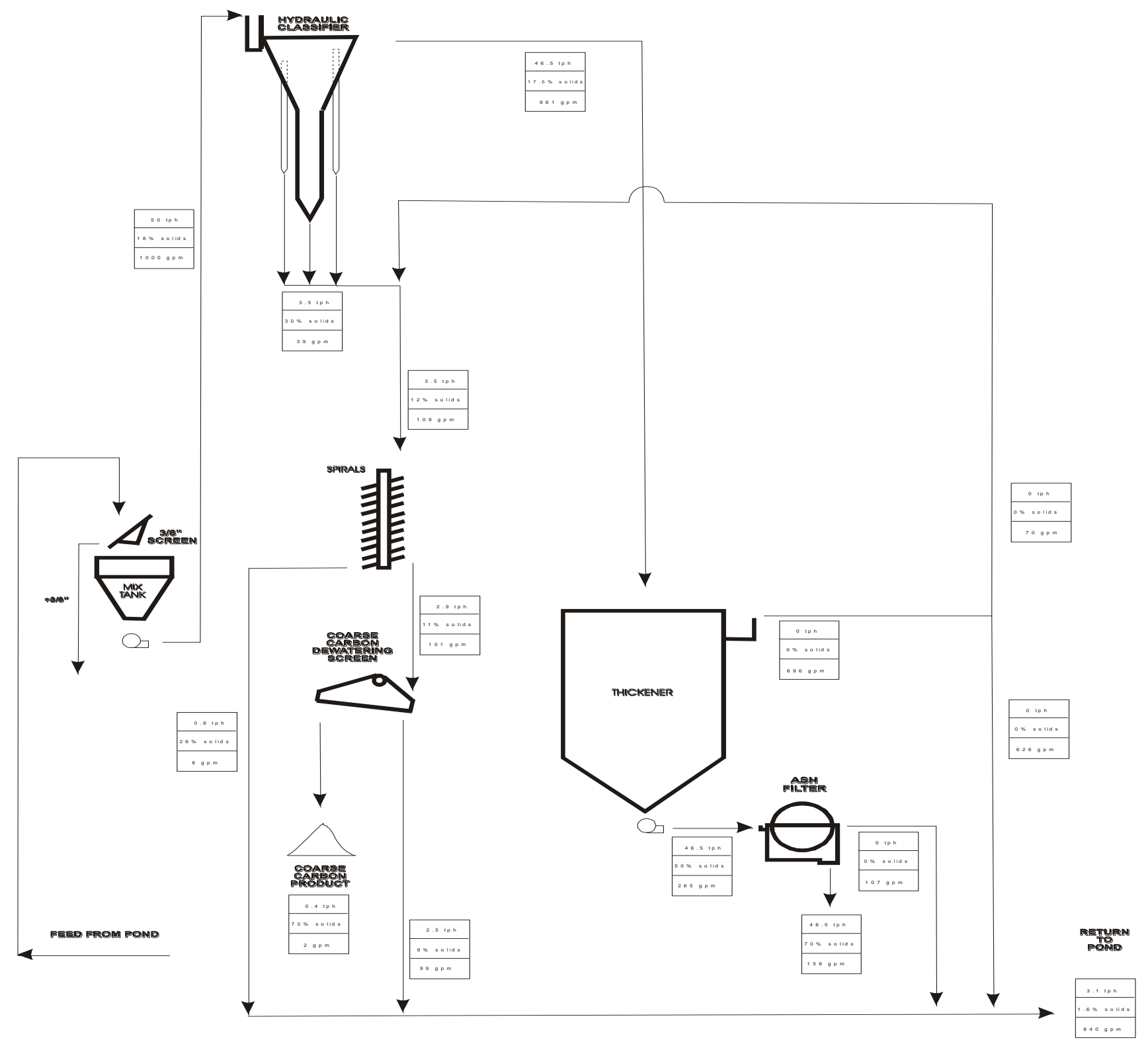

Figure 1. Process Flowsheet 1. 
Flowsheet 2: Flowsheet 2 (Figure 2) is the same as Flowsheet 1, with the addition of froth flotation. With this configuration, the primary classifier overflow reports to froth flotation to remove fine carbon. As such, three different products are produced; coarse carbon, fine carbon and pozzolan.

The primary classifier overflow (46.5 tph, $17.5 \%$ solids) reports to froth flotation where the appropriate amount of reagents are added. Reagents consist of a fuel oil-based collector (SPP) to selectively adsorb onto the fine carbon to render the surfaces hydrophobic, and a water soluble glycol-based frother, to reduce surface tension and provide sufficient air bubble surface area and stability to remove hydrophobic carbon. The flotation design basis and reagent requirements were derived from pilot-scale testing. By incorporating flotation, a froth product is generated ( $2.8 \mathrm{tph}, 10 \%$ solids) which may potentially be used as a fuel. To do so requires an additional vacuum filter. Based on manufacturer testing, 30\% moisture cake is achievable with the use of flocculant. Carbon filter effluent contains water soluble frother, which may be recirculated back to the flotation feed to reduce frother consumption. Doing so dilutes flotation feed; however, pilot testing showed that despite reduced pulp density in the flotation feed, froth solids remained essentially consistent at $10 \%$ solids. The net result will be dilution of the flotation tailings to less than the designed $18.5 \%$ solids, well within the operating range of the static thickener. The thickener and filter parameters are essentially the same as for Flowsheet 1, with pozzolan production reduced to 43.7 tph since the differential 2.8 tph was recovered as a froth product. The net return to the pond is $3.1 \mathrm{tph}$ at $1.8 \%$ solids. 


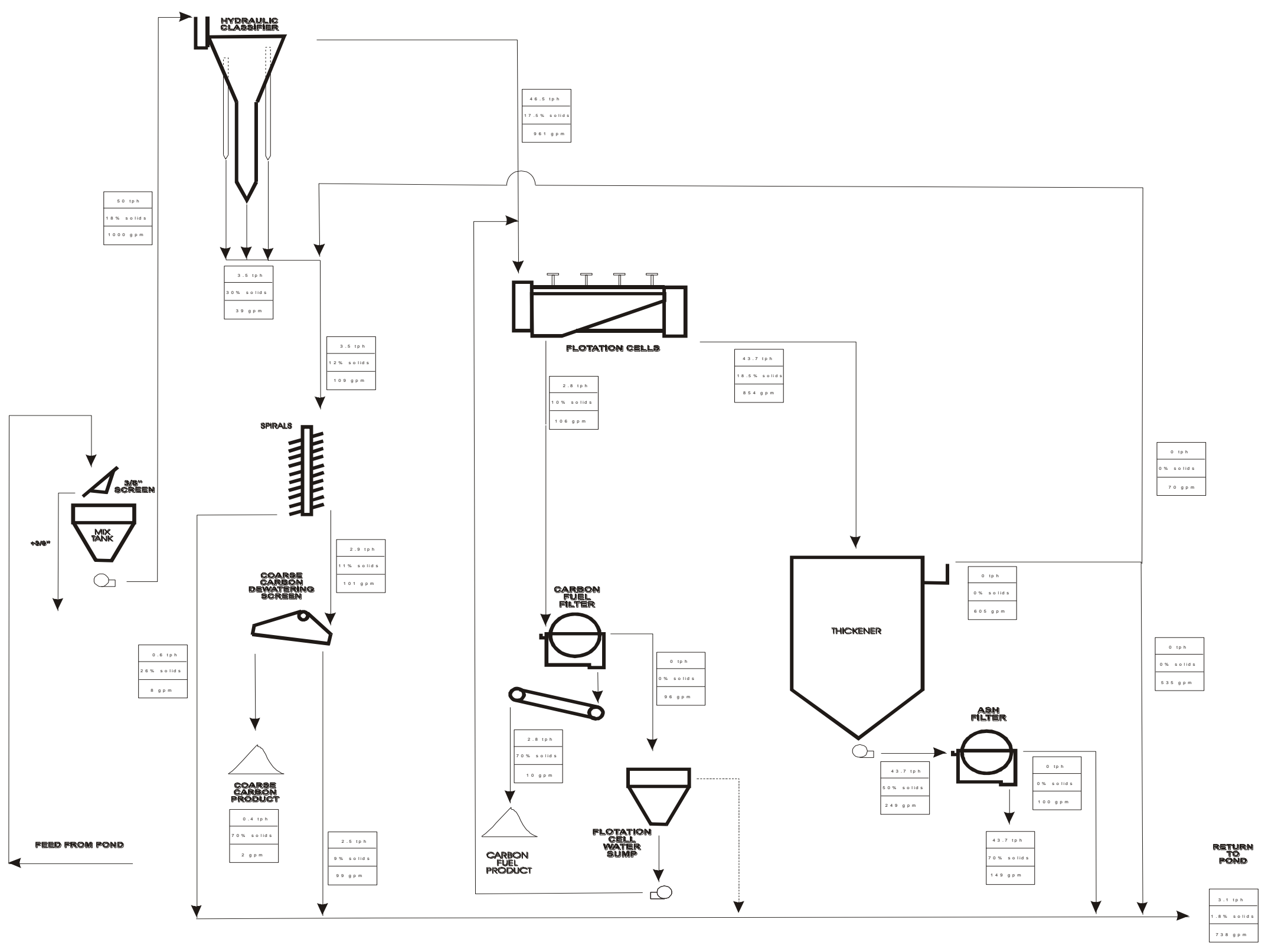

Figure 2. Process Flowsheet 2. 
Flowsheet 3: Flowsheet 3 (Figure 3) is the same as Flowsheet 1, with the addition of secondary classification. With this configuration, the primary classifier overflow reports to the secondary classifier to recover the finest particles (i.e. $<10 \mu \mathrm{m}$ ), thus two products are produced; coarse carbon and ultra-fine ash (UFA).

The primary classifier overflow $(46.5 \mathrm{tph}, 17.5 \%$ solids $)$ reports to the secondary classifier where the appropriate amount of dispersant $(1-2 \mathrm{~g} / \mathrm{kg})$ is added. The dispersant used in pilot-scale evaluations was a water soluble naphthalene sulfonate (NSF) to effectively disperse the finest particulates. The dispersed slurry is fed into a secondary classifier which consists essentially of a rectangular tank with lamella plates aligned parallel to the feed flow and sloped to the base of the tank at $45^{\circ}$. The lamella plates serve as settling surfaces for coarse particles (i.e. $>10 \mu \mathrm{m}$ ) to effectively remove them from suspension as they settle. Coarse particles accumulate on the plates and slide to the bottom of the tank where they accumulate as thickened sediment and are removed and returned to the pond. The total sediment underflow is 32.5 tph at $60 \%$ solids, derived from pilot-scale testing. This product is potentially marketable as pozzolan, but was not considered in the economic evaluation.

The dispersed fine particulates flow to the end of the classifier and overflow as a dilute slurry through vented, submerged pipes. The pipes are vented to prevent siphoning and are submerged to allow cenospheres, coarse $(>150 \mu \mathrm{m})$ hollow ash spheres, to accumulate on the top of the slurry. The cenospheres can readily be collected at this point as a marketable product, but were not considered as a product in the economic evaluation.

The overflow (14 tph at $6.7 \%$ solids) reports to a thickener where flocculant (5 ppm PEO) is added to improve settling rate and clarity. Thickener underflow design is $50 \%$ solids, which was readily achieved in pilot-scale studies, even without the use of thickener rakes. The thickener clarified water overflow is returned to the pond, except for spiral feed dilution water.

The thickener underflow is dewatered to $30 \%$ solids on a vacuum drum filter. This cake moisture was readily achieved in pilot-scale studies. Filter studies provided solids capture of $80-85 \%$. Most of the solids lost in filtration were through leaks in media seals against the drum, a situation not likely to occur with a larger filter.

Nevertheless, provisions are made in the plant design to return the filter effluent back to the thickener to maximize UFA recovery.

With this flowsheet design, 0.4 tph coarse carbon is recovered along with 14 tph UFA. A total of 35.6 tph solids are returned to the pond at $13.4 \%$ solids. Additional products that are potentially recoverable include magnetite, cenospheres and pozzolan. 


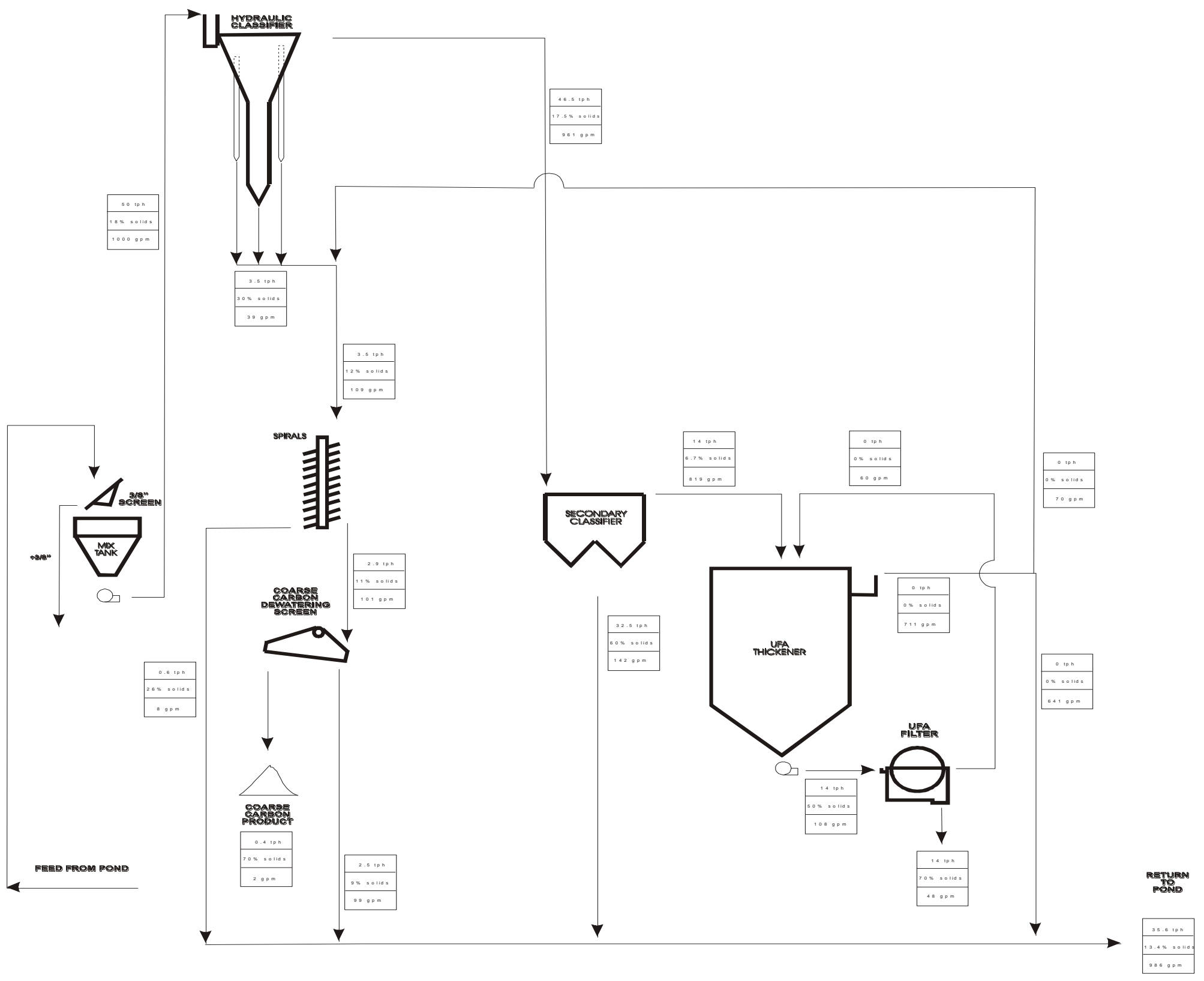

Figure 3. Process Flowsheet 3. 
Flowsheet4: Flowsheet 4 (Figure 4) is the most complex circuit and includes primary classification, spiral concentration, flotation and secondary classification. The unit processes produce coarse carbon fuel, fine carbon fuel and UFA as primary products. Potential additional products include magnetite, cenospheres and pozzolan, but were not considered in the economic evaluation.

The primary classifier and spiral circuit are the same as shown in the other flowsheets. The primary classifier overflow reports to flotation and flow regimes and reagent additions are the same as for the flotation circuit described for Flowsheet 2; the froth product ( 2.8 tph at $10 \%$ solids) will again be dewatered with a vacuum filter to $30 \%$ moisture.

Dispersant (1-2 $\mathrm{g} / \mathrm{kg} \mathrm{NSF})$ is added to the flotation tailings (43.7 tph at $18.5 \%$ solids) and the reagentized slurry flows into the secondary classifier where fine particulates $(<10 \mu \mathrm{m})$ are dispersed and coarse $(>10 \mu \mathrm{m})$ particulates accumulate on inclined lamella plates and are removed as thickened sediment. The fine particulate slurry (13.1 tph at $6.6 \%$ solids) overflows the secondary classifier and is thickened to $50 \%$ solids in the UFA thickener before being dewatered on a vacuum filter to $30 \%$ moisture.

With this configuration, three primary products are produced; 0.4 tph coarse carbon fuel, 2.8 tph fine carbon fuel and 13.1 tph UFA. The slurry returned to the pond contains 33.7 tph solids at $13.7 \%$ slids. Additional products that are potentially recoverable include magnetite, cenospheres and pozzolan. 


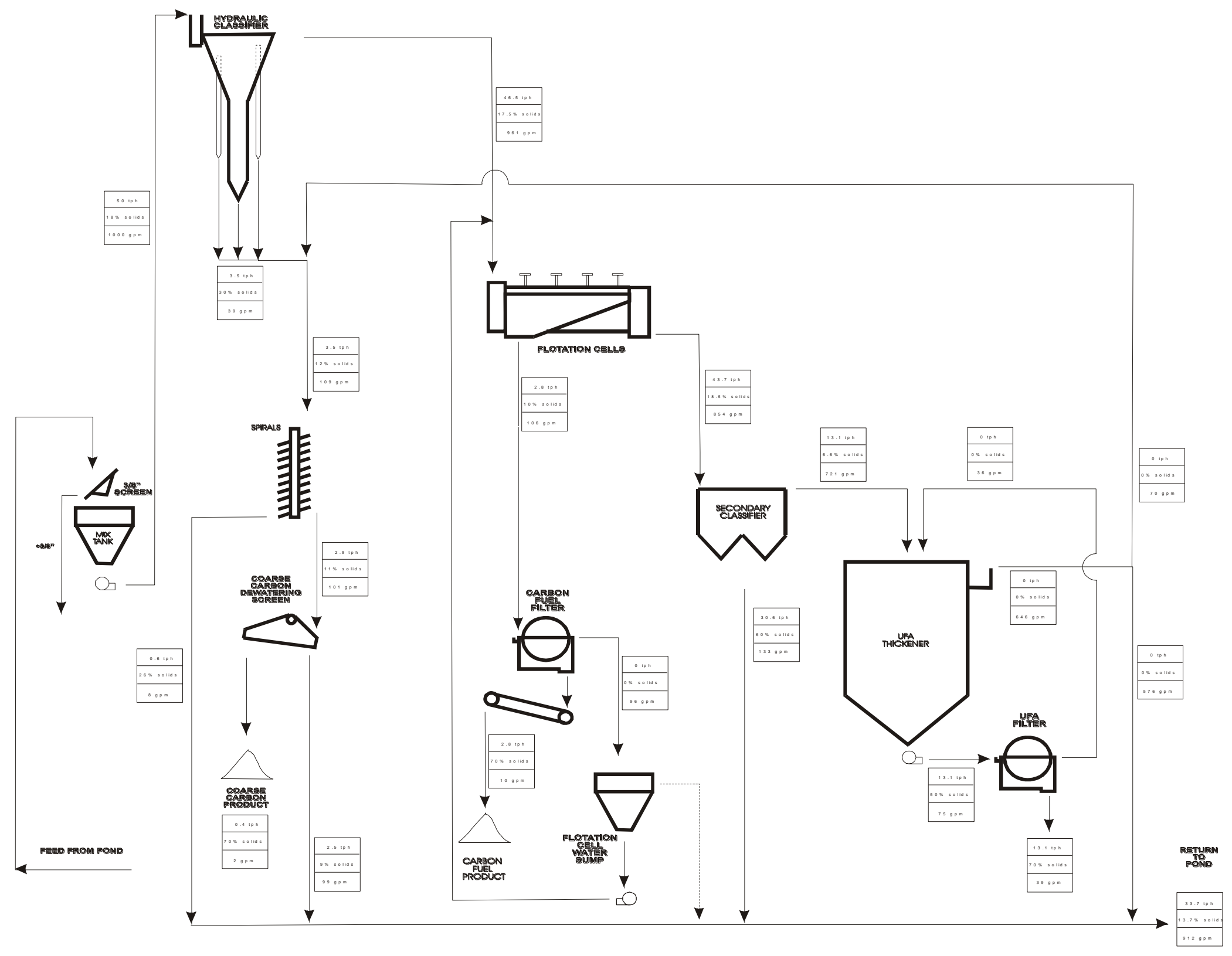

Figure 4. Process Flowsheet 4. 


\section{Plant Costs}

A summary of plant costs are shown in the following tables and are divided sections for each unit process (i.e. feed system, classification, flotation, etc.). Within each unit process section is a list of the specific items and the sizes or capacities required, horsepower and quantity needed. A description of the size justification will be provided later in this report. After determining the size of equipment needed, verbal price quotes were requested from various vendors or other appropriate sources. The source of the price quotes is included. In order to determine the installation cost, a price estimating procedure commonly used in the coal preparation and mineral industry was used. This procedure entailed defining an installation factor which is multiplied by the capital cost to estimate the installed equipment cost. The installation factors used (Table 4) were provided from several companies involved with coal preparation and mineral processing plant construction and modification.

\begin{tabular}{|lc|}
\hline \multicolumn{1}{|c|}{ Table 4. Determination of Equipment Installation Factors. } \\
\hline \multicolumn{1}{|c|}{ Level of Work Required } & Installation Factor \\
\hline Placement & 1 \\
\hline Placement \& Mounting or Bracing & 1.5 \\
\hline $\begin{array}{l}\text { Placement, Mounting or Bracing and Electrical } \\
\text { Connection }\end{array}$ & 2 \\
\hline $\begin{array}{l}\text { Placement, Mounting or Bracing, Electrical } \\
\text { Connection and Controls }\end{array}$ & 2.5 \\
\hline
\end{tabular}


Table 5. Equipment List and Cost Estimate for Flowsheet 1.

Flowsheet 1

Hydraulic Classification

Products: Pozzolan, Coarse Carbon

Unit Operation

\begin{tabular}{|c|c|}
\hline & Item \\
\hline \multicolumn{2}{|l|}{ Plant Feed System } \\
\hline & Dredge \\
\hline & 3/8" Trash Screen \\
\hline & Feed Slurry Tank \\
\hline & Feed Mixer \\
\hline & Classifier Feed Pump \\
\hline \multicolumn{2}{|l|}{ Classification } \\
\hline & Lewis Econosizer \\
\hline & Varisieve \\
\hline \multicolumn{2}{|l|}{ Spirals } \\
\hline & Spiral Feed Sump \\
\hline & Spiral Feed Pump \\
\hline & Spirals, Distributor, Fittings \\
\hline & Coarse Carbon Dewatering Screen \\
\hline & Screen Underflow Sump \\
\hline & Screen Underflow Pump \\
\hline & Screen Underflow Pump Motor \\
\hline & Carbon Conveyor \& Motor \\
\hline \multicolumn{2}{|l|}{ Ash Dewatering } \\
\hline & Flocculant Make-up and Metering System \\
\hline & Tailings Thickener,Rakes \& Controls \\
\hline & Thickener Underflow Pump and Motor \\
\hline & Pozzolan Vacuum Filter \& Accessories \\
\hline & Pozzolan Conveyor \& Motor \\
\hline \multicolumn{2}{|l|}{ Product Storage } \\
\hline & Pozzolan Stacker/Reclaimer \\
\hline & Damp Pozzolan Storage Facility \\
\hline & Truck Loadout, Dust Collector, Loading Spouts, etc. \\
\hline & Truck Scales \\
\hline \multicolumn{2}{|l|}{ Miscellaneous } \\
\hline & Clarified Water Sump \\
\hline & Clarified Water Pump and Motor \\
\hline & Make-Up Water Supply Pump \\
\hline & Piping \\
\hline & Instrumentation and Control \\
\hline & Plant Building \\
\hline & Utility Building \\
\hline & Electrical Transmission Line \& Sub-station \\
\hline
\end{tabular}

Capacity
or Size
$50 \mathrm{tph}$
$3^{\prime} \times 6^{\prime}$
$1000 \mathrm{gal}$
$1000 \mathrm{gpm}$
$17^{\prime} \times 17^{\prime}$

$\begin{array}{ll}\text { hp } & \text { Quantity } \\ & \\ 50 & 1 \\ & 1 \\ & 1 \\ 20 & 1 \\ 50 & 1 \\ & \\ & \\ & \\ & 1\end{array}$

$\begin{array}{ccc}\text { Total hp } & \begin{array}{c}\text { Capital } \\ \text { Cost }\end{array} & \begin{array}{c}\text { Total Capital } \\ \text { Cost }\end{array} \\ 50 & \$ 253,460 & \$ 253,460 \\ & \$ 16,744 & \$ 16,744 \\ 20 & \$ 13,512 & \$ 13,512 \\ & \$ 11,436 & \$ 11,436 \\ & \$ 18,860 & \$ 18,860 \\ & & \\ & \$ 149,500 & \$ 149,500 \\ & \$ 6,900 & \$ 6,900\end{array}$

$\begin{array}{cr}\begin{array}{c}\text { Installation } \\ \text { Factor }\end{array} & \begin{array}{c}\text { Total Installed } \\ \text { Cost }\end{array} \\ 1.5 & \$ 380,190 \\ 1.5 & \$ 25,116 \\ 1.5 & \$ 20,268 \\ 2.5 & \$ 28,590 \\ 1.5 & \$ 28,290 \\ & \\ 1.5 & \$ 224,250 \\ 1.5 & \$ 10,350\end{array}$

Subtotals

Price Source

$\begin{array}{lr}500 \mathrm{gal} & \\ 100 \mathrm{gpm} & 15 \\ \text { Bank of } & \text { Triple Starts } \\ 4^{\prime} \times 8^{\prime} & 10 \\ 100 \mathrm{gallon} & \\ 50 \mathrm{gpm} & \\ 24^{\prime \prime} \times 40^{\prime} & 5 \\ & 2\end{array}$

$\$ 1,087$

$\$ 1,000$

$\$ 3,910 \quad \$ 3,910$

$\$ 13,800 \quad \$ 13,800$

$\$ 1,087 \quad \$ 1,087$

$\$ 1,133 \quad \$ 1,133$

$\$ 25,645 \quad \$ 25,645$

$0.1 \mathrm{gpm}$

$40^{\prime}$ diam $\times 12^{\prime}$

$200 \mathrm{gpm}$

$700 \mathrm{ft} 2$

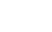

$\$ 25,645$

$\$ 2,875$

$\$ 2,875$

$\begin{array}{rrr} & \$ 2,875 & \$ 2,875 \\ 10 & \$ 207,000 & \$ 207,000 \\ 30 & \$ 1,435 & \$ 1,435\end{array}$

$30 \quad \$ 1,435$

$\$ 268,824$

$\$ 537,648$

25

25
10

$25 \quad \begin{array}{r}\$ 78,890 \\ \$ 112,961\end{array} \quad \$ 18,890$

$\$ 56,879 \quad \$ 56,879$

$\$ 36,018$

$1000 \mathrm{gal}$

$50 \mathrm{gpm}$

$\$ 1,880 \quad \$ 1,880$

$\$ 1,087 \quad \$ 1,087$

$\$ 2,283 \quad \$ 2,283$

$\$ 10,000 \quad \$ 10,000$

$\$ 15,000 \quad \$ 15,000$

$\begin{array}{ll}\$ 57,500 & \$ 57,500 \\ \$ 69,000 & \$ 69,000\end{array}$

Electrical Transmission Line \& Sub-station

Subtotals

Engineering Design \& Construction

Mobilization and Demobilization

Construction Overhead-Secretarial, Accounting, etc.

$\begin{array}{rrrl}1.5 & \$ 1,500 & & \\ 2.5 & \$ 9,775 & & \text { Goulds:reconditioned } \\ 1.5 & \$ 8,241 & & \text { PrepTech, Inc. } \\ 2 & \$ 27,600 & & \text { Tabor: reconditioned } \\ 1.5 & \$ 941 & & \\ 1.5 & \$ 1,631 & & \\ 2.5 & \$ 2,833 & & \text { Mine and Mill Engineering } \\ 1.5 & \$ 38,468 & \$ 90,987 & \\ & & & \text { Cytec, Inc. } \\ 1.5 & \$ 4,313 & & \text { Westec } \\ 1.5 & \$ 310,500 & & \text { Grainger Industrial Supply } \\ 1.5 & \$ 2,153 & & \text { Westec } \\ 2.5 & \$ 1,344,120 & & \text { surplusrequest.com } \\ 1.5 & \$ 31,050 & & \\ & & \$ 1,692,135 & \\ 1.5 & \$ 118,335 & & \text { Mine and Mill Engineering } \\ 1.5 & \$ 169,442 & & \\ 1.5 & \$ 85,319 & & \text { Mine and Mill Engineering } \\ 1.5 & \$ 54,027 & & \text { National Minerals Corp } \\ & & \$ 427,122 & \\ 1 & \$ 1,880 & & \text { Mine and Mill Engineering } \\ 1.5 & \$ 1,631 & & \text { Mine and Mill Engineering } \\ 2.5 & \$ 5,708 & & \text { Goulds:reconditioned } \\ 1.5 & \$ 15,000 & & \\ 1.5 & \$ 15,000 & & \\ 1.5 & \$ 22,500 & & \\ 1.5 & \$ 86,250 & & \text { Mine and Mill Engineering } \\ 1.5 & \$ 103,500 & \$ 251,468 & \\ & & & \\ & & & \\ & \$ 3,178,766 & \$ 3,178,766 & \\ & \$ 10,000 & & \text { Mine and Mill Engineering } \\ & \$ 15,000 & & \text { Mine and Mill Engineering } \\ & & & \end{array}$


roject Supervision

Equipment Rental (2 months)

Total
$\$ 20,000$

$\$ 20,000$

$\$ 65,000$

$\$ 3,243,766$ Mine and Mill Engineering
Mine and Mill Engineering 
Table 6. Equipment List and Cost Estimate for Flowsheet 2.

Flowsheet 2

Hydraulic Classification, Flotation

Products: Pozzolan, Coarse Carbon, Fine Carbon

Unit Operation

\begin{tabular}{|c|c|c|c|c|c|c|c|c|c|c|c|}
\hline & Item & $\begin{array}{l}\text { Capacity } \\
\text { or Size }\end{array}$ & $\mathrm{hp}$ & Quantity & $\begin{array}{c}\text { Total } \\
\mathrm{hp}\end{array}$ & $\begin{array}{c}\text { Capital } \\
\text { Cost }\end{array}$ & $\begin{array}{l}\text { Total } \\
\text { Capital } \\
\text { Cost }\end{array}$ & $\begin{array}{l}\text { Installation } \\
\text { Factor }\end{array}$ & $\begin{array}{l}\text { Total } \\
\text { Installed } \\
\text { Cost }\end{array}$ & Subtotals & Price Source \\
\hline \multicolumn{12}{|l|}{$\begin{array}{l}\text { Plant Feed } \\
\text { System }\end{array}$} \\
\hline & Dredge & $50 \mathrm{tph}$ & 50 & 1 & 50 & $\$ 253,460$ & $\$ 253,460$ & 1.5 & $\$ 380,190$ & & \multirow{3}{*}{$\begin{array}{l}\text { IMS } \\
\text { Charah Environmental } \\
\text { Mine and Mill } \\
\text { Engineering }\end{array}$} \\
\hline & 3/8" Trash Screen & $3^{\prime} \times 6^{\prime}$ & & 1 & & $\$ 16,744$ & $\$ 16,744$ & 1.5 & $\$ 25,116$ & & \\
\hline & Feed Slurry Tank & $1000 \mathrm{gal}$ & & 1 & & $\$ 13,512$ & $\$ 13,512$ & 1.5 & $\$ 20,268$ & & \\
\hline & Feed Mixer & & 20 & 1 & 20 & $\$ 11,436$ & $\$ 11,436$ & 2.5 & $\$ 28,590$ & & \multirow{3}{*}{$\begin{array}{l}\text { Lightnin, Inc. } \\
\text { Mine and Mill } \\
\text { Engineering }\end{array}$} \\
\hline & Classifier Feed Pump & $1000 \mathrm{gpm}$ & 50 & 1 & & $\$ 18,860$ & $\$ 18,860$ & 1.5 & $\$ 28,290$ & & \\
\hline \multicolumn{11}{|l|}{ Classification } & \\
\hline 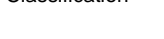 & Lewis Econosizer & $17^{\prime} \times 17^{\prime}$ & & 1 & & $\$ 149,500$ & $\$ 149,500$ & 1.5 & $\$ 224,250$ & & \multirow{3}{*}{$\begin{array}{l}\text { Lewis Minerals Corp } \\
\text { Krebs:reconditioned }\end{array}$} \\
\hline & Varisieve & 60 Mesh & & 1 & & $\$ 6,900$ & $\$ 6,900$ & 1.5 & $\$ 10,350$ & & \\
\hline & & & & & & & & & & $\$ 234,600$ & \\
\hline \multicolumn{12}{|l|}{ Spirals } \\
\hline & Spiral Feed Sump & $500 \mathrm{gal}$ & & 1 & & $\$ 1,087$ & $\$ 1,000$ & 1.5 & $\$ 1,500$ & & \multirow{6}{*}{$\begin{array}{l}\text { Goulds:reconditioned } \\
\text { PrepTech, Inc. } \\
\text { Tabor: reconditioned }\end{array}$} \\
\hline & Spiral Feed Pump & $100 \mathrm{gpm}$ & 15 & 1 & & $\$ 3,910$ & $\$ 3,910$ & 2.5 & $\$ 9,775$ & & \\
\hline & Spirals, Distributor, Fittings & Bank of Triple & Starts & 2 & & $\$ 2,747$ & $\$ 5,494$ & 1.5 & $\$ 8,241$ & & \\
\hline & Coarse Carbon Dewatering Screen & $4 ' \times 88^{\prime}$ & 10 & 1 & & $\$ 13,800$ & $\$ 13,800$ & 2 & $\$ 27,600$ & & \\
\hline & Screen Underflow Sump & 100 gallon & & 1 & & $\$ 627$ & $\$ 627$ & 1.5 & $\$ 941$ & & \\
\hline & Screen Underflow Pump & $50 \mathrm{gpm}$ & & 1 & & $\$ 1,087$ & $\$ 1,087$ & 1.5 & $\$ 1,631$ & & \\
\hline & Screen Underflow Pump Motor & & 5 & 1 & 5 & $\$ 1,133$ & $\$ 1,133$ & 2.5 & $\$ 2,833$ & & \multirow{3}{*}{$\begin{array}{l}\text { Mine and Mill } \\
\text { Engineering }\end{array}$} \\
\hline & Carbon Conveyor \& Motor & $24 " \times 40^{\prime}$ & 2 & 1 & & $\$ 25,645$ & $\$ 25,645$ & 1.5 & $\$ 38,468$ & & \\
\hline & & & & & & & & & & $\$ 90,987$ & \\
\hline \multirow{7}{*}{ Flotation } & & & & & & & & & & & \multirow{7}{*}{$\begin{array}{l}\text { Denver Equipment } \\
\text { Co. } \\
\text { US Plastic Corp } \\
\text { US Plastic Corp } \\
\text { Grainger Industrial } \\
\text { Supply } \\
\text { Fluid Metering, Inc. }\end{array}$} \\
\hline & Flotation Cells,Motors, Launders, etc. & $600 \mathrm{ft} 3$ & 15 & 1 & 150 & $\$ 135,700$ & $\$ 135,700$ & 1.5 & $\$ 203,550$ & & \\
\hline & Bulk Reagent Storage & $2000 \mathrm{gal}$ & & 2 & & $\$ 1,037$ & $\$ 2,074$ & 1.5 & $\$ 3,111$ & & \\
\hline & Reagent Day Tanks & $200 \mathrm{gal}$ & & 2 & & $\$ 232$ & $\$ 464$ & 1.5 & $\$ 696$ & & \\
\hline & Reagent Transfer Pumps & $3 \mathrm{gpm}$ & 1 & 2 & 2 & $\$ 205$ & $\$ 410$ & 1.5 & $\$ 615$ & & \\
\hline & Reagent Metering Pumps & $0.1 \mathrm{gpm}$ & & 4 & & $\$ 644$ & $\$ 2,576$ & 1.5 & $\$ 3,864$ & & \\
\hline & & & & & & & & & & $\$ 211,836$ & \\
\hline \multicolumn{12}{|l|}{$\begin{array}{l}\text { Carbon } \\
\text { Dewatering }\end{array}$} \\
\hline & Carbon Vacuum Filter \& Accessories & $210 \mathrm{ft} 2$ & 290 & 1 & 290 & $\$ 207,000$ & $\$ 207,000$ & 2.5 & $\$ 517,500$ & & \multirow{3}{*}{$\begin{array}{l}\text { Westec } \\
\text { surplusrequest.com }\end{array}$} \\
\hline & Carbon Conveyor \& Motor & $100 \mathrm{ft}$ & 2 & 1 & & $\$ 20,700$ & $\$ 20,700$ & 1.5 & $\$ 31,050$ & & \\
\hline & & & & & & & & & & $\$ 548,550$ & \\
\hline \multirow{7}{*}{ Ash Dewatering } & & & & & & & & & & & \\
\hline & Flocculant Make-up and Metering System & $\begin{array}{l}0.1 \mathrm{gpm} \\
40^{\prime} \operatorname{diam} \mathrm{X}\end{array}$ & & 1 & & $\$ 2,875$ & $\$ 2,875$ & 1.5 & $\$ 4,313$ & & Cytec, Inc. \\
\hline & Tailings Thickener, Rakes \& Controls & & 10 & 1 & 10 & $\$ 207,000$ & $\$ 207,000$ & 1.5 & $\$ 310,500$ & & \multirow{5}{*}{$\begin{array}{l}\text { Westec } \\
\text { Grainger Industrial } \\
\text { Supply } \\
\text { Westec } \\
\text { surplusrequest.com }\end{array}$} \\
\hline & Thickener Underflow Pump and Motor & $200 \mathrm{gpm}$ & 30 & 1 & 30 & $\$ 1,435$ & $\$ 1,435$ & 1.5 & $\$ 2,153$ & & \\
\hline & Pozzolan Vacuum Filter \& Accessories & $700 \mathrm{ft} 2$ & 285 & 2 & 570 & $\$ 268,824$ & $\$ 537,648$ & 2.5 & $\$ 1,344,120$ & & \\
\hline & Pozzolan Conveyor \& Motor & $100 \mathrm{ft}$ & 2 & 1 & & $\$ 20,700$ & $\$ 20,700$ & 1.5 & $\$ 31,050$ & & \\
\hline & & & & & & & & & & $\$ 1,692,135$ & \\
\hline Product Storage & Pozzolan Stacker/Reclaimer & & 25 & 1 & 25 & $\$ 78,890$ & $\$ 78,890$ & 1.5 & $\$ 118,335$ & & Mine and Mill \\
\hline
\end{tabular}


Damp Pozzolan Storage Facility

Truck Loadout, Dust Collector, Loading Spouts, etc.

Truck Scales

Miscellaneous

Clarified Water Sump
Clarified Water Pump and Motor
Make-Up Water Supply Pump
Piping
Instrumentation and Control
Plant Building
Utility Building
Electrical Transmission Line \& Sub-station

$\begin{array}{ll}1000 \mathrm{gal} & \\ 50 \mathrm{gpm} & 5 \\ 50 \mathrm{gpm} & 5 \\ & \\ & \\ & \\ & \end{array}$

Subtotals

Engineering Design \& Construction

Mobilization and Demobilization

Construction Overhead-Secretarial, Accounting, etc.

Project Supervision

Equipment Rental (2 months)
$\$ 56,8$

$\$ 36,018$

$\$ 56,879$

$\$ 36,018$

$1.5 \$ 169,442$

$\$ 85,319$

$\$ 54,027$

$\$ 427,12$

National Minerals

Corp

Mine and Mill

Engineering

Engineering

Goulds:reconditioned

$\$ 1,631$

$\$ 15,000$

$\begin{array}{llll}\$ 10,000 & \$ 10,000 & 1.5 & \$ 15,000 \\ \$ 10,000 & \$ 10,000 & 1.5 & \$ 15,000 \\ \$ 15,000 & \$ 15,000 & 1.5 & \$ 22,500\end{array}$

$\begin{array}{llll}\$ 15,000 & \$ 15,000 & 1.5 & \$ 22,500 \\ \$ 57,500 & \$ 57,500 & 1.5 & \$ 86,250\end{array}$

$\$ 103,500$

Mine and Mill

$\$ 251,468$

Engineering

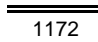

$\overline{\$ 2,113,188}$

$\$ 3,939,152 \quad \$ 3,939,152$

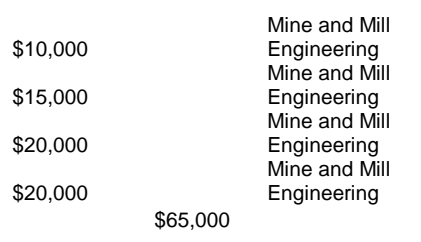

$\$ 4,004,152$ 
Table 7. Equipment List and Cost Estimate for Flowsheet 3.

Flowsheet 3

Hydraulic Classification,

Products: UFA, Coarse Carbon

Unit

\begin{tabular}{ll} 
Plant Feed System & \multicolumn{1}{c}{ Item } \\
& Dredge \\
& 3/8" Trash Screen \\
& Feed Slurry Tank \\
& Feed Mixer \\
& Classifier Feed Pump \\
Classification & \\
& \\
& Lewis Econosizer \\
Spirals & \\
& \\
& Spiral Feed Sump \\
& Spiral Feed Pump \\
& Spirals, Distributor, Fittings \\
& Coarse Carbon Dewatering Screen \\
& Screen Underflow Sump \\
& Screen Underflow Pump \\
& Screen Underflow Pump Motor \\
& Carbon Conveyor \& Motor
\end{tabular}

$\begin{array}{llr}\begin{array}{l}\text { Capacity } \\ \text { or Size }\end{array} & \text { hp } & \text { Quantity } \\ \begin{array}{l}\text { 50 tph } \\ 3^{\prime} \times 6^{\prime}\end{array} & 50 & 1 \\ 1000 \mathrm{gal} & & 1 \\ & & 1 \\ 1000 \mathrm{gpm} & 50 & 1 \\ & & \end{array}$

Total
hp Capital

Total
Capital
Cost

Installation

Total

Cost

Subtotals

Price Source

$50 \$ 253,460$

$\$ 253,460$
$\$ 16,744$

$\$ 380,190$
$\$ 25,116$

IMS

$20 \quad \begin{aligned} & \$ 13,512 \\ & \$ 11,436\end{aligned}$

$\$ 13,512$

$\$ 20,268$

$\$ 28,590$

$\$ 18,860$

$\$ 18,860$

$\$ 28,290$

$17^{\prime} \times 17^{\prime}$

$\$ 149,500$

$\$ 224,250$

$\begin{array}{lr}500 \text { gal } & \\ 100 \mathrm{gpm} & 15 \\ \text { Bank of } & \text { Triple Starts } \\ 4{ }^{\prime} \times 8^{\prime} & 10 \\ 100 \text { gallon } & \\ 50 \mathrm{gpm} & 5 \\ & \\ 24^{\prime \prime} \times 40^{\prime} & 2\end{array}$

UFA Classification

UFA Classifier

ulk Reagent Storage

$$
\$ 1,087
$$

$$
\begin{aligned}
& \$ 1,087 \\
& \$ 3,910 \\
& \$ 2,747
\end{aligned}
$$$$
\$ 2,747
$$$$
\$ 13,800
$$$$
\$ 627
$$$$
\$ 1,087 \quad \$ 1,087
$$$$
\$ 1,133
$$

$\$ 25,645$

$\$ 25,645$

$\$ 1,000$

$\$ 3,910$

$\$ 5,494$

$24^{\prime \prime} \times 40^{\prime}$

150

$\begin{array}{rr}\$ 135,700 & \$ 135,700 \\ \$ 1,037 & \$ 1,037 \\ \$ 232 & \$ 232 \\ & \\ \$ 205 & \$ 205 \\ \$ 644 & \$ 644 \\ \$ 2,500 & \$ 10,000\end{array}$

Reagent Transfer Pumps
Reagent Metering Pumps Underflow Pumps \& Motors

2000 gal

200 gal

$3 \mathrm{gpm}$

$5 \mathrm{gpm}$

$\$ 10,000$

Ash

Dewatering

Flocculant Make-up and Metering

System Thickener Underflow Pump and Motor
Pozzolan Vacuum Filter \& Pozzolan Vacu
Accessories

$0.1 \mathrm{gpm}$

$40^{\prime}$ diam X

$200 \mathrm{gpm}$

$700 \mathrm{ft} 2$

$100 \mathrm{ft}$

Pozzolan Conveyor \& Motor

Product

Pozzolan Stacker/Reclaimer

Damp Pozzolan Storage Facility

Truck Loadout, Dust Collector, Loading Spouts, etc.

$\$ 2,875$

537,648

$\begin{array}{rll}\$ 1,500 & & \\ \$ 9,775 & & \text { Goulds:reconditioned } \\ \$ 8,241 & & \text { PrepTech, Inc. } \\ \$ 27,600 & & \text { Tabor: reconditioned } \\ \$ 941 & & \\ \$ 1,631 & & \\ \$ 2,833 & & \text { Mine and Mill } \\ \$ 38,468 & & \text { Engineering }\end{array}$

$\$ 203,550$

$\begin{aligned} \$ 1,556 & \text { US Plastic Corp } \\ \$ 348 & \text { US Plastic Corp } \\ & \text { Grainger Industrial } \\ \$ 308 & \text { Supply } \\ \$ 966 & \text { Fluid Metering, Inc. } \\ \$ 25,000 & \end{aligned}$

$\$ 206,727$

Cytec, Inc.

Westec

Grainger Industrial

Supply

Westec

$\$ 1,344,120$

$\$ 1,692,135$

Mine and Mill
Engineering

Mine and Mill 
Truck Scales

Miscellaneous

Clarified Water Sump

Clarified Water Pump and Moto

Make-Up Water Supply Pump

Piping

Instrumentation and Control

Plant Building

Utility Building

Subtotals

Engineering Design \& Construction

Mobilization and Demobilization

Construction Overhead-Secretarial, Accounting, etc.

\section{Project Supervision}

Equipment Rental (2 months)

\begin{tabular}{|c|c|c|c|c|c|}
\hline & & 1 & & $\$ 36,018$ & $\$ 36,018$ \\
\hline $1000 \mathrm{gal}$ & & 1 & & $\$ 1,880$ & $\$ 1,880$ \\
\hline $50 \mathrm{gpm}$ & 5 & 1 & 5 & $\$ 1,087$ & $\$ 1,087$ \\
\hline \multirow[t]{6}{*}{$50 \mathrm{gpm}$} & 5 & 1 & 5 & $\$ 2,283$ & $\$ 2,283$ \\
\hline & & 1 & & $\$ 10,000$ & $\$ 10,000$ \\
\hline & & 1 & & $\$ 10,000$ & $\$ 10,000$ \\
\hline & & 1 & & $\$ 15,000$ & $\$ 15,000$ \\
\hline & & 1 & & $\$ 57,500$ & $\$ 57,500$ \\
\hline & & 1 & & $\$ 69,000$ & $\$ 69,000$ \\
\hline
\end{tabular}

889 $\overline{\$ 1,885,182}$
Engineering

National Minerals Corp

Mine and Mill

Engineering
Mine and Mill
Engineering

Goulds:reconditioned

Mine and Mill

Engineering

$\$ 251,468$

$\$ 3,400,143 \quad \$ 3,375,143$

\begin{tabular}{|c|c|}
\hline & Mine and Mill \\
\hline 10,000 & $\begin{array}{l}\text { Engineering } \\
\text { Mine and Mill }\end{array}$ \\
\hline$\$ 15,000$ & $\begin{array}{l}\text { Engineering } \\
\text { Mine and Mill }\end{array}$ \\
\hline & $\begin{array}{l}\text { Engineering } \\
\text { Mine and Mill } \\
\text { Engineering }\end{array}$ \\
\hline & \\
\hline
\end{tabular}

$\$ 3,440,143$ 
Table 8. Equipment List and Cost Estimate for Flowsheet 4.

Flowsheet 4

Hydraulic Classification, Flotation

UFA

Unit Operation

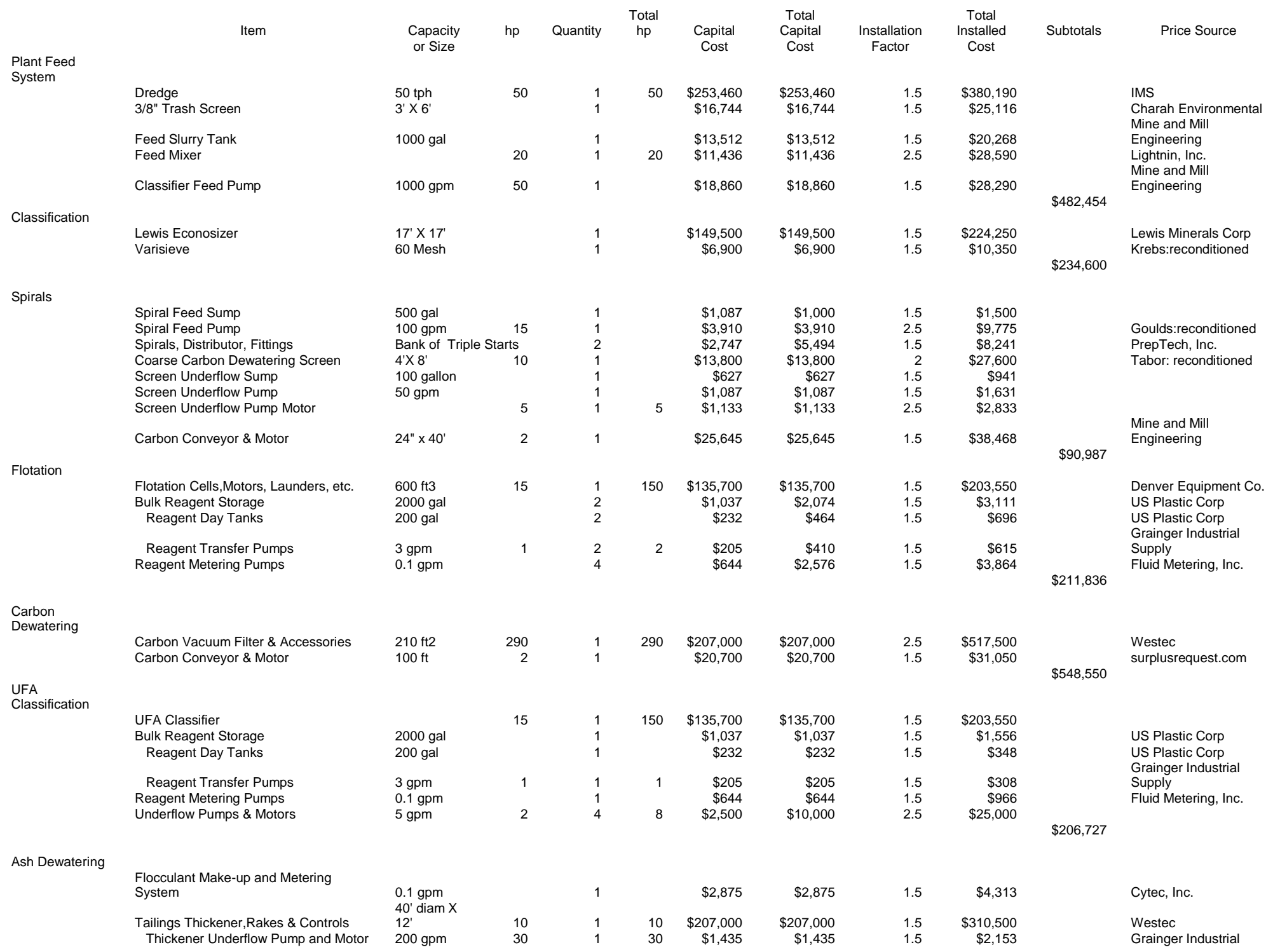




\begin{tabular}{|c|c|c|c|c|c|c|c|c|c|c|c|}
\hline & $\begin{array}{l}\text { Pozzolan Vacuum Filter \& Accessories } \\
\text { Pozzolan Conveyor \& Motor }\end{array}$ & $\begin{array}{l}700 \mathrm{ft} 2 \\
100 \mathrm{ft}\end{array}$ & $\begin{array}{r}285 \\
2\end{array}$ & $\begin{array}{l}2 \\
1\end{array}$ & 570 & $\begin{array}{r}\$ 268,824 \\
\$ 20,700\end{array}$ & $\begin{array}{r}\$ 537,648 \\
\$ 20,700\end{array}$ & $\begin{array}{l}2.5 \\
1.5\end{array}$ & $\begin{array}{r}\$ 1,344,120 \\
\$ 31,050\end{array}$ & & $\begin{array}{l}\text { Supply } \\
\text { Westec } \\
\text { surplusrequest.com }\end{array}$ \\
\hline \multirow{6}{*}{ Product Storage } & & & & & & & & & & $\$ 1,692,135$ & \\
\hline & & & & & & & & & & & Mine and Mill \\
\hline & Pozzolan Stacker/Reclaimer & & 25 & 1 & 25 & $\$ 78,890$ & $\$ 78,890$ & 1.5 & $\$ 118,335$ & & Engineering \\
\hline & Damp Pozzolan Storage Facility & & & & & $\$ 112,961$ & $\$ 112,961$ & & & & Mine and Mill \\
\hline & $\begin{array}{l}\text { Truck Loadout, Dust Collector, Loading S } \\
\text { Truck Scales }\end{array}$ & puts, etc. & 10 & $\begin{array}{l}1 \\
1\end{array}$ & 10 & $\begin{array}{l}\$ 56,879 \\
\$ 36,018\end{array}$ & $\begin{array}{l}\$ 56,879 \\
\$ 36,018\end{array}$ & $\begin{array}{l}1.5 \\
1.5\end{array}$ & $\begin{array}{l}\$ 85,319 \\
\$ 54,027\end{array}$ & & $\begin{array}{l}\text { Engineering } \\
\text { National Minerals Corp }\end{array}$ \\
\hline & & & & & & & & & & $\$ 427,122$ & \\
\hline \multicolumn{12}{|l|}{ Miscellaneous } \\
\hline & Clarified Water Sump & $1000 \mathrm{gal}$ & & 1 & & $\$ 1,880$ & $\$ 1,880$ & 1 & $\$ 1,880$ & & $\begin{array}{l}\text { Mine and Mill } \\
\text { Engineering } \\
\text { Mine and Mill }\end{array}$ \\
\hline & Clarified Water Pump and Motor & $50 \mathrm{gpm}$ & 5 & 1 & 5 & $\$ 1,087$ & $\$ 1,087$ & 1.5 & $\$ 1,631$ & & Engineering \\
\hline & Make-Up Water Supply Pump & $50 \mathrm{gpm}$ & 5 & 1 & 5 & $\$ 2,283$ & $\$ 2,283$ & 2.5 & $\$ 5,708$ & & Goulds:reconditioned \\
\hline & Piping & & & 1 & & $\$ 10,000$ & $\$ 10,000$ & 1.5 & $\$ 15,000$ & & \\
\hline & Instrumentation and Control & & & 1 & & $\$ 10,000$ & $\$ 10,000$ & 1.5 & $\$ 15,000$ & & \\
\hline & Plant Building & & & 1 & & $\$ 15,000$ & $\$ 15,000$ & 1.5 & $\$ 22,500$ & & \\
\hline & Utility Building & & & 1 & & $\$ 57,500$ & $\$ 57,500$ & 1.5 & $\$ 86,250$ & & \\
\hline & $\begin{array}{l}\text { Electrical Transmission Line \& Sub- } \\
\text { station }\end{array}$ & & & 1 & & $\$ 69,000$ & $\$ 69,000$ & 1.5 & $\$ 103,500$ & & $\begin{array}{l}\text { Mine and Mill } \\
\text { Engineering }\end{array}$ \\
\hline & & & & & & & & & & $\$ 251,468$ & \\
\hline Subtotals & & & & & 1331 & & $\$ 2,261,006$ & & $\$ 4,170,879$ & $\$ 4,145,879$ & \\
\hline \multicolumn{12}{|c|}{ Engineering Design and Construction } \\
\hline & & & & & & & & & & & \multirow{5}{*}{$\begin{array}{l}\text { Mine and Mill } \\
\text { Engineering } \\
\text { Mine and Mill } \\
\text { Engineering } \\
\text { Mine and Mill } \\
\text { Engineering } \\
\text { Mine and Mill } \\
\text { Engineering }\end{array}$} \\
\hline & Mobilization and Demobilization & & & & & & & & $\$ 10,000$ & & \\
\hline & Construction Overhead-Secretarial, Accol & ting, etc. & & & & & & & $\$ 15,000$ & & \\
\hline & Project Supervision & & & & & & & & $\$ 20,000$ & & \\
\hline & Equipment Rental (2 months) & & & & & & & & $\$ 20,000$ & & \\
\hline Total & & & & & & & & & & $\$ 4,210.879$ & \\
\hline
\end{tabular}


Table 9 provides a summary of the estimated construction costs of a 50 tph plant for each of the four process flowsheet configurations considered along with the principle products produced with each flowsheet. Principle product production rates were determined from pilot-scale testing conducted at the Ghent site. Additional products such as magnetite, cenospheres, aggregate and additional pozzolan may be recovered form the various process streams but were not considered in this evaluation summary.

\section{Table 9. Summary of Installed Plant Costs and Products Produced.}

\begin{tabular}{|lcccc|}
\hline Flowsheet & 1 & 2 & 3 & 4 \\
\hline Total Cost & $\$ 3.24 \mathrm{M}$ & $\$ 4.00 \mathrm{M}$ & $\$ 3.44$ & $\$ 4.21 \mathrm{M}$ \\
\hline Principle Products Produced & & & & \\
\hline Pozzolan, tph & 46.5 & 43.7 & - & - \\
\hline UFA, tph & - & - & 14.0 & 13.1 \\
\hline Coarse Carbon, tph & 0.4 & 0.4 & 0.4 & 0.4 \\
\hline Fine Carbon, tph & - & 2.8 & - & 2.8 \\
\hline Total Principle Products, tph & 46.9 & 46.9 & 14.4 & 16.3 \\
\hline Plant Product Yield, \% & 93.8 & 93.8 & 28.8 & 32.6 \\
\hline
\end{tabular}




\section{Conclusions}

\section{Technical Highlights of Budget Period 1.}

Coring activities revealed that the lower ash pond at Ghent Station contains over 7 million tons of ash, including over 1.5 million tons of coarse carbon and 1.8 million tons of fine $(<10 \mu \mathrm{m})$ glassy pozzolanic material. These potential products are primarily concentrated in the lower end of the pond adjacent to the outlet.

A representative bulk sample was excavated for conducting laboratory-scale process testing while a composite 150 ton sample was also excavated for demonstrationscale testing at the Ghent site. A mobile demonstration plant with a design feed rate of 2.5 tph was constructed and hauled to the Ghent site to evaluate unit processes (i.e. primary classification, froth flotation, spiral concentration, secondary classification, etc.) on a continuous basis to determine appropriate scale-up data.

Unit processes were configured into four different flowsheets and operated at a feed rate of 2.5 tph to verify continuous operating performance and generate bulk (1 to 2 tons) products for product testing. Cementitious products were evaluated for performance in mortar and concrete as well as cement manufacture process addition. All relevant data from the four flowsheets was compiled to compare product yields and quality while preliminary flowsheet designs were generated to determine throughputs, equipment size specifications and capital cost summaries.

The best results obtained with primary classification were met at a feed rate of 40 to $60 \mathrm{gpm}$. Higher feed rate results in poor classification and poor rejection of coarse solids while lower feed rate diminishes both yield and recovery of ultrafines. In regards to feed solids, operating at high feed solids (i.e. $25 \%$ ) provided reduced rejection of +100 mesh solids when the feed rate was higher than $40 \mathrm{gpm}$.

Release analysis showed that froth flotation could effectively be used to reduce the classified ash from $4.5 \%$ LOI to the target grade of $2.5 \%$ LOI with a yield as high as $90 \%$. A minimum retention time of 6 minutes was required to provide LOI reduction to $2.5 \%$ LOI using $1.2 \mathrm{lbs} /$ ton collector and $0.23 \mathrm{lbs} /$ ton frother. Reagent costs to provide acceptable grade tailings were 0.50 to $1.00 \$ /$ ton of flotation feed. The collector used (SPP) was a mixture of $90 \%$ \#2 fuel oil and $10 \%$ petroleum sulfonate while the frother was Ciba F948, a water soluble mixed glycol product. Demonstration plant flotation results were consistent with release analysis results, indicating that no further significant improvement in flotation performance could be expected with additional testing.

The proper flocculant to provide satisfactory thickening and clarity results on the UFA product is PEO at a dosage of $5 \mathrm{ppm}$ on a slurry basis. These conditions provide a settling rate of 6 inches/minute and settled solids concentrations of over $50 \%$ solids by weight. PEO has been used in numerous concrete applications as a viscosity reducer and will not present any adverse effects to cement chemistry, particularly when used at such a minimal dosage. Maximum throughput of the thickened slurry with continuous vacuum filtration was $115 \mathrm{lb} / \mathrm{hr}$ dry cake rate $(25 \mathrm{lb} / \mathrm{ft} 2 / \mathrm{hr})$ and was achieved at a cycle time of 1.25 minutes. Under these conditions the cake moisture was $30.5 \%$ with $85 \%$ solids capture. Increasing cycle time not did not reduce cake moisture but did reduce the dry cake rate and throughput. 
Dryer evaluations were conducted in consultation with thermal dryer manufacturers familiar with the application and product end use. To produce a dry product, fuel requirement will be 1100 Btu to evaporate 1 pound of water. Considering the scale of the proposed operation and volatility of fuel prices, the use of thermal drying presents a serious economic impediment to the successful completion of this project. An even greater challenge is the air permits required to construct and operate a dryer at the proposed facility.

As expected, flowsheets not incorporating secondary classification produced products that were coarser. As such, the levels of water reduction achieved by these coarser products when tested in mortar were also lower. The primary classification product (EP) product achieved a Strength Activity Index (SAI) of 85\% of control strength in 7 days, $100 \%$ in 28 days and $130 \%$ in 56 days. The froth flotation product (FP) product performed similarly after 7 and 28 days, but achieved only $103 \%$ of control in 56 days. The highest strengths were obtained with the finer products produced by secondary classification with (FUFA) and without (UFA) flotation. Several bulk products were produced under a variety of operating conditions, with the finest products producing the higher strengths. Both UFA and FUFA products provided SAI of 102 to $110 \%$ of control in 7 days and 126 to $140 \%$ of control in 56 days. The higher dosages of air entraining admixture (AEA) to achieve constant air for the finer products is attributed primarily to increased fineness.

Concrete testing was conducted using a Kentucky Transportation Pavement Mix design and substituting locally available Trimble ash or UFA at a substitution rate of $20 \%$. The Trimble ash achieved $87 \%$ of control strength after 7 days and increased to $102 \%$ after 56 days. Two series of tests were conducted with UFA and although there were some differences particularly for the early strengths, the UFA outperformed the Trimble ash with $87-90.5 \%$ of control after 7 days, 105 to $107 \%$ after 28 days and 109.5 to $112 \%$ after 56 days.

Another series of concrete cylinders were poured using a Kentucky Transportation Cabinet High Performance Mix Design (MA designation). The UFA cylinders showed an expected delay in strength development during the early stages of curing and outperformed the control after approximately 20 days.

At 5\% UFA substitution, SAI was $101 \%$ after 1 and 7 days and increased to $106 \%$ after 28 days. At $15 \%$ substitution, SAI decreased to $89.5 \%$ after 1 day and $98 \%$ after 7 days, but the longer term strength gains were apparent after 28 days as a SAI of $113 \%$ was attained. At $25 \%$ substitution, early strengths were diminished and again, a SAI of $119.5 \%$ was achieved after 28 days. At the highest substitution level tested (35\%), early strengths were the lowest and SAI increased to $105 \%$ after 28 days. These results illustrate that higher substitution levels certainly delay early strength development, but surpass control strength after 28 days while lower substitution levels provide both early and longer term strength.

One of the most significant benefits provided by using UFA in concrete mix designs is the improved resistance to chloride permeability. While it has been known for some time that using fly ash in concrete reduces permeability, using finer ash provides a significant improvement in this criterion. Chloride permeability testing was conducted 
using four different concrete mixes: control, 20\% Trimble ash, 20\% UFA, and 40\% UFA. Chloride permeability was improved when Trimble ash was used. Significant further reductions were demonstrated when UFA was used, achieving an ASTM Chloride Rating of Very Low.

The effect of Trimble ash and UFA on concrete flexural and tensile strength were also evaluated. Results showed that marginal improvements in flexural strength were realized with Trimble ash and were somewhat higher when UFA was used in the mix design. Tensile strength was essentially unchanged when UFA was used and decreased for the Trimble ash.

Despite the above mentioned technical merits of this technology, market developments in the Ohio River Valley area during 2006-2007 were not conducive to demonstrating the project at the scale proposed in the Cooperative Agreement. As a result, Cemex withdrew from the project in 2006 citing unfavorable local market conditions at the demonstration site. Although CAER had generated interest in the technology, a financial commitment to proceed to Budget Period 2 could not be obtained from private companies. Thus, CAER concurred with the USDoE to conclude the project at the end of Budget Period 1, March 31, 2007. 